This manuscript version is the "Accepted Author Manuscript" - the final published article detail is below and may be accessed via the DOI link provided:

Rivett, M.O., Halcrow, A.H., Schmalfuss, J., Stark, J.A., Truslove, J.P., Kumwenda, S., Harawa, K.A., Nhlema, M., Songola, C., Wanangwa, G.J., Miller, A.V.M., Kalin, R.M., 2018. Local scale water-food nexus: Use of borehole-garden permaculture to realise the full potential of rural water supplies in Malawi. Journal of Environmental Managemen,209, 354-370. https://doi.org/10.1016/i.jenvman.2017.12.029

\title{
Local scale water-food nexus: use of borehole-garden permaculture to realise the full potential of rural water supplies in Malawi
}

\author{
Michael O. Rivett ${ }^{1}$, Alistair W. Halcrow ${ }^{1}$, Janine Schmalfuss ${ }^{1}$, John A. Stark ${ }^{1,2}$, Jonathan P. \\ Truslove $^{1}$, Steve Kumwenda ${ }^{3}$, Kettie A. Harawa ${ }^{3}$, Muthi Nhlema ${ }^{4}$, Chrispine Songola ${ }^{5}$, Gift J. \\ Wanangwa ${ }^{6}$, Alexandra V.M. Miller ${ }^{1}$, Robert M. Kalin ${ }^{1}$
}

${ }^{1}$ Department of Civil and Environmental Engineering, University of Strathclyde, Glasgow, G1 1XJ, UK

${ }^{2}$ Now at: EnviroCentre Ltd, Craighall Business Park, 8 Eagle Street, Glasgow, G4 9XA, UK

${ }^{3}$ Water For People - Malawi, PO Box 1207, Blantyre, Malawi

${ }^{4}$ BASEflow, Galaxy House, Blantyre, Malawi (formerly: Water for People - Malawi)

${ }^{5}$ District Water Development Office, Chikwawa District Council, Private Bag 1, Chikwawa. Malawi

${ }^{6}$ Ministry of Agriculture, Irrigation and Water Development, Regional Irrigation and Water Development Office - South, Private Bag 13, Blantyre, Malawi

Corresponding author: michael.rivett@strath.ac.uk 


\section{Highlights}

- Borehole-garden permaculture: spilt groundwater use for water-food-health security

- Technical/socioeconomic issues to address for successful permaculture identified

- Framework for borehole-garden permaculture implementation developed

- Economic benefit: water-point maintenance, micro-loan access, spin-out business

- A fraction of permaculture's greater potential for rural communities to be explored

\section{Graphical abstract}

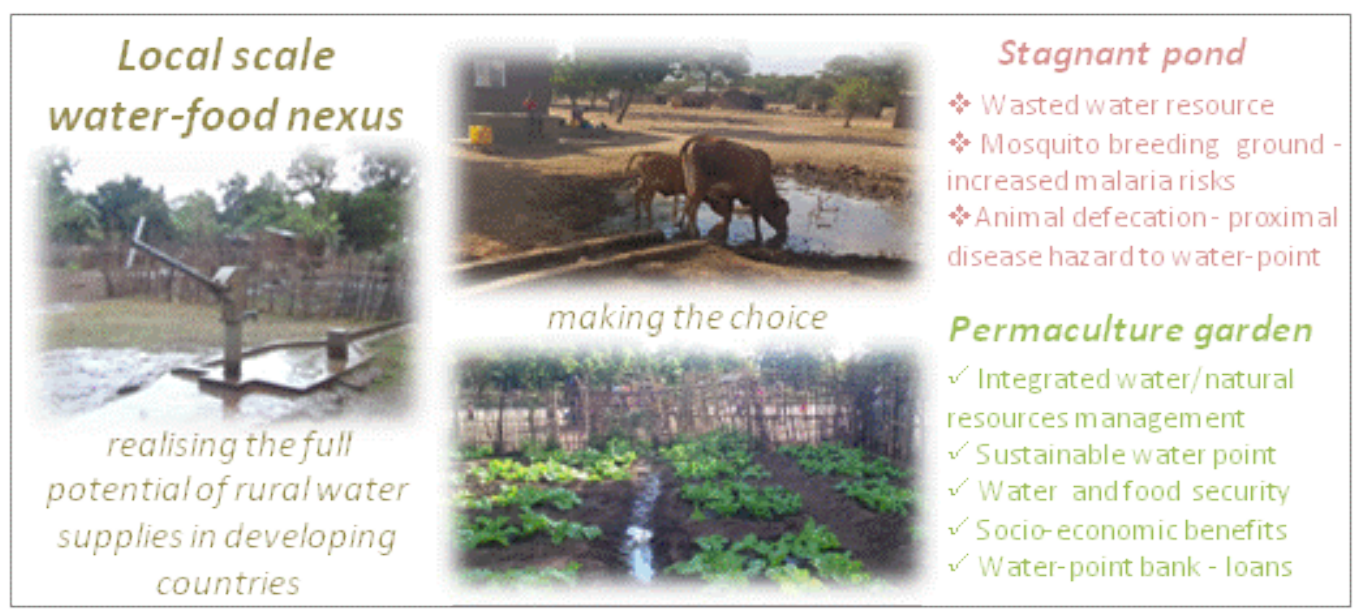

\section{Abstract}

Local-scale opportunities to address challenges of the water-food nexus in the developing world need to be embraced. Borehole-garden permaculture is advocated as one such opportunity that involves the sustainable use of groundwater spilt at hand-pump operated borehole supplies that is otherwise wasted. This water may also pose health risks when accumulating as a stagnant pond. Rural village community use of this grey-water in permaculture projects to irrigate borehole gardens is proposed to primarily provide economic benefit whereby garden-produce revenue helps fund borehole water-point maintenance. Water-supply sustainability, increased food/nutrition security, health protection from malaria, and business opportunity benefits also arise. Our goal has been to develop an, experience-based, framework for delivery of sustainable borehole-garden permaculture and associated benefits. This is based upon data collection and permaculture implementation across the rural Chikwawa District of Malawi during 2009-17. We use, stakeholder interviews to identify issues influencing uptake, gathering of stagnant pond occurrence data to estimate amelioration 
opportunity, quantification of permaculture profitability to validate economic potential, and critical assessment of recent permaculture uptake to identify continuing problems. Permaculture was implemented at 123 sites representing $6 \%$ of District water points, but with $26 \%$ coverage in one area. Most implementations were at, or near, newly drilled community-supply boreholes; hence, amelioration of prevalent stagnant ponds elsewhere remains a concern. The envisaged benefits of permaculture were manifest and early data affirm projected garden profitability and spin-off benefits of water-point banking and community micro-loan access. However, a diversity of technical, economic, social and governance issues were found to influence uptake and performance. Example issues include greater need for improved bespoke garden design input, on-going project performance assessment, and coordinated involvement of multi-sector governmental-development bodies to underpin the integrated natural-resource management required. The developed framework aims to manage the identified issues; it demands the concerted action of all stakeholders. Based on the expected ubiquity of underlying issues, it is expected to be generalizable to the wider developing world. This particular application of permaculture represents a fraction of its greater potential opportunity for rural communities that should be explored.

Keywords: permaculture; water-food nexus; integrated water resources management (IWRM); groundwater; sustainability; Malawi

\section{Introduction}

Opportunities to address the challenges of the water-food nexus at the local-community scale should be proactively embraced. This is especially true in the rural developing world, particularly Sub-Saharan Africa (SSA) where water and food security concerns may abound within impoverished conditions. Malawi is a low-income country, amongst the least developed globally (UN CfDP, 2016). Most of its 17 million people reside in rural areas where a series of issues pervade that demographic. Water is central to survival and issues that stem from Malawi's water problems are many (Mulwafu et al., 2003). The sustained delivery of safe drinking water represents a major challenge. Agriculture, central to the economy, is critically dependent upon water, particularly rainfall that falls seldom outside of the wet season. Frequent drought and flood events ruin crops and impinge upon the 
national yield and cause food insecurity (ActionAid, 2006; Branca et al., 2016). Southern Malawi is particularly vulnerable to such events and possible climate-change exacerbation. Many small-scale farmers produce less food than they need to consume and may need to resort to buying food at the market, especially during the lean season (Ellis and Manda, 2012). Some may go hungry as prices of staple crops increase during that season.

Tens of thousands of boreholes, 'water points', exist across Malawi that provide drinking and domestic water supply to rural village communities (Pavelic, 2012). The vast majority have been installed under international aid programmes facilitated by NGOs (non-governmental organisations) in liaison with the Malawian government. Most boreholes are fitted with hand pumps allowing villagers to pump and collect their own water supply for drinking, washing and other domestic use. The collection process may, however, involve spillage of abstracted groundwater. This is not only a waste, but also constitutes a health hazard as spilt water frequently accumulates in stagnant ponds. These unfortunately provide mosquito breeding grounds leading to increased malaria risks (Ecological Society of America, 2011); Southern Malawi is a malaria-endemic area. Moreover, ponds may also serve as watering holes for animals and hence become a proximal disease hazard to the water point due to animal defecation nearby. A further consideration is that funds need to be generated to sustainably maintain a water point thereby freeing the community from aid support. Key concerns are hence to realise the full potential of abstracted groundwater and adjoining land resources, avoid water and land waste, minimise health risks, and deliver sustainable water supply alongside other benefits, notably increased food security and socioeconomic benefit. Our contention, actively progressed in Malawi since 2009, is that 'borehole-garden permaculture' may provide an elegant solution to these concerns and deliver a range of benefits to a participating local community.

Permaculture was founded in the 1970 s as a system of agricultural and social design principles that synergistically and adaptively centres upon natural ecosystems (Holmgren, 2002). It encourages the best use of natural resources without waste and continues to be innovated upon globally (Akhtar et al., 2016; Birnbaum and Fox, 2014; Bradley, 2014; Greenblott and Nordin, 2017; Hemenwey, 2015; Mancebo and De la Fuente de Val, 2016; Vitari and David, 2017). Modern-day permaculture embraces: "Consciously designed landscapes which mimic the patterns and relationships found in nature, while yielding an abundance of food, fibre and energy for provision of local needs. People, their buildings and the ways in which they organise themselves are central to permaculture. Thus the permaculture vision of permanent or sustainable agriculture has evolved to one of permanent or 
sustainable culture." (Holmgren Design, 2017). Malawi is no stranger to permaculture. Pioneering work by the Nordin family (with the US Peace Corps) in the 1990s was triggered by the need for HIV prevention and care. They critically recognised that permaculture could provide a sustainable solution to the malnutrition, food insecurity, and poverty issues that undermined achievement of their health-related goal (Nordin and Nordin, 2014). The value of permaculture to Malawi's localscale development of food and nutrition security is increasingly being recognised (Vidal, 2016).

Our concept of, village community, borehole-garden permaculture involves the collection of abstracted groundwater spilt in the vicinity of hand-pumps. This collected 'grey water' is channelled into a fenced-off permaculture garden area where it is distributed, ideally passively, throughout the cropped garden area. Year-round water availability allows for a perennial food source opportunity, including the lean season. Garden produce is sold to raise income to help fund water-point maintenance, lower tariffs and possibly fund other enterprise. Stagnant ponds and associated health risks are thereby removed. The approach constitutes a local-scale application of integrated water resources management (IWRM) and realises sustainable use of water and land natural resources (Hoko and Hertle, 2006). It engenders a 'grassroots', community participative, approach (Kishindo, 2003; Hussein, 2003; Mulwafu and Msosa, 2005), albeit recognising the community-based groundwater management paradigm pervasive across rural SSA is not a panacea (Van Den Broek and Brown, 2015).

The primary novelty of such a borehole-garden permaculture approach, at least for Malawi at the inception of our work from 2009, and it would seem internationally, is the proactive utilisation of borehole wastewater together with delivery of circular-economy benefit. This emphasis contrasts with handpump-borehole community gardens typically found in the literature where there is purposeful abstraction of groundwater for irrigation use, so-called 'small or micro-irrigation' schemes. Such schemes do, however, tend to realise a range of benefit type not dissimilar to those illustrated by borehole-garden permaculture herein. The pioneering work in Zimbabwe of Lovell et al. (1996) and Waughway et al. (1998) is particularly illustrative of the significant community benefit that is possible through a proactive small-irrigation scheme involving a reasonably large-area community-garden approach.

Our research focuses upon the Chikwawa District within Southern Malawi where water, food and health-security issues abound. Our overarching goal is to develop a strategic framework for effective borehole-garden permaculture implementation and management. Impetus for this ambition is 
provided by our early observations of relatively low uptake of permaculture. Moreover, when implemented, some gardens were failing and becoming abandoned, even returning to stagnant pond conditions. Our multifaceted approach to this goal, with underpinning activity spanning 200917, comprises:

- Stakeholder interviews in 2012-13 (Halcrow, 2013) to identify confounding technical, economic, social and governance issues that impinge upon permaculture performance (supplemented by interview data from our companion IWRM study of Schmalfuss (2014));

- Surveying of borehole stagnant pond occurrence across Chikwawa to assess the opportunity for targeted reduction of waste water and health risks;

- Scoping calculations to establish the economic value of permaculture;

- Critical assessment of recent permaculture uptake to identify the current status and continuing issues; involving, evaluation of promotion activity, recent (2015-16) mapping of permaculture occurrence, and very recent (2017) informal review of some projects.

The developed framework is hence research, multi-stakeholder, and implementation-experience informed. It is based upon a collaborative university, NGO, national/local governmental body and village community participation effort. It also recognises that a framework should ideally be 'generalizable' to the wider developing world; stagnant-pond occurrence, the need for sustainable water-point funding, and water-food security concerns, are common concerns globally.

\section{Materials and methods}

\subsection{Study setting}

The Chikwawa District $\left(4,800 \mathrm{~km}^{2}\right)$ has a population approaching 500,000 that is dispersed across the Shire River valley plain and surrounding foothills (Fig. 1). Most people live in, frequently impoverished, village farming communities. The District is subdivided into eight Traditional Authority (TA) and two Senior Traditional Authority jurisdictions. It is semi-arid and one of the hottest parts of Malawi. The mean temperature is $25.7^{\circ} \mathrm{C}$ and the annual rainfall is $800 \mathrm{~mm}$. The valley plain is prone to both flood and drought with most rainfall occurring in the rainy seasons that spans several months. The area is vulnerable to climate-change influence.

Chikwawa is highly reliant upon groundwater for village (domestic) and agricultural supply. Village abstraction is typically from a borehole central to a community fitted with a hand pump (Water Aid, 
2013). Groundwater is primarily abstracted from the alluvial flood plain aquifer, and possibly fractured basement rock aquifer towards the plain margins (Smith-Carrington and Chilton, 1983). Groundwater development remains an active priority; a programme was initiated in 2013 to drill over a thousand supply boreholes across Chikwawa to help the District meet the United Nations' Millennium Development Goal 7 - Target 10 (UN, 2014). The local objective is to provide one borehole for at least every 250 people within 500 m of a served community (Water For People, pers. commun., 2014).

Concerning study-relevant governances, the District Executive Committee (DEC) holds overarching responsibility for the District Development Plan (DDP) implemented by their District Co-ordinating Team (DCT) (Chiweza, 2010). Members of the DEC include the various Malawian government ministries, including the Ministry of Agriculture, Irrigation and Water Development, the Ministry of Education, Science and Technology, and the Ministry of Health (hence referred to in abbreviated form focusing on the relevant sector, e.g., 'Ministry of Agriculture'). Relevant officers working for these bodies appear within the tabulation of interview stakeholders introduced below. Together, these ministries may significantly influence permaculture success. At the local community scale, each village has a chief responsible for directing villager efforts, making important decisions on their behalf and liaising with government officials and visitors. At the water-point (borehole) scale, a Water Point Committee (described later) is responsible for that community facility.

\subsection{Interviews}

Stakeholder interviews conducted in Chikwawa in 2013 covering a varied set of stakeholders (Table 1) used standard qualitative interview techniques (Bryman, 2012; Halcrow, 2013). Interviewee selection was based upon positional responsibilities, awareness of governmental and societal structure and involvement with a facilitating NGO. The latter was primarily Water for People Malawi. An open and closed question semi-structured interview approach, bespoke to interviewee type, gave direction with flexibility. Tabulated questions for Agricultural Extension Workers are illustrated in Table SM-1 of the Supplementary Material (SM). Generated 'Mind-maps' from each interview summarise the specific contexts and required efforts that could foster permaculture success. Interviews conducted in groups on occasion may have constrained responses, albeit adding other dynamics. Our companion research of Schmalfuss (2014) conducted similar stakeholder interviews set within a wider IWRM scope; relevant aspects of these interviews are drawn upon. 


\subsection{Survey of borehole - stagnant pond occurrence}

The occurrence of stagnant ponds associated with boreholes across Chikwawa was surveyed in 2013 in collaboration with Department of Health and Sanitation staff (Halcrow, 2013). Mapping was undertaken by Health Surveillance Assistants (HSAs) who reported to the Environmental Health Officer (EHO). The assembled dataset of pond occurrence was compared to Water For People's FLOW database of water points. 474 mapped stagnant pond occurrences were confirmed, but with 86 data points lost due to difficulties in marrying the two datasets (spelling errors and uncertain identification of some location names). The total number of water points checked was unfortunately not confirmed and hence percentage occurrence required estimation (see later).

\subsection{Assessment of local IWRM promotion}

A questionnaire-based survey assessed the impact of our (Water For People) earlier (2012 onwards) promotion of an IWRM approach that targeted 18 villages within the Chapananga TA (Fig. 1). This initiative included training of communities and other stakeholders on IWRM and primarily aimed to introduce borehole-garden permaculture as a key opportunity. Training was provided on the technical development of income-generating gardens, including life-cycle costing.

\subsection{Assessment of current (2015-17) permaculture status}

Collation of water-point data (into the FLOW database) to generate a robust 'asset register' continues to form a key priority for the author organisations. Water-point mapping data were obtained primarily by formal questionnaire surveys using Water For People enumerators. Only since 2015 have questions been included that address borehole - garden permaculture development and stagnant pond occurrence. Presentation of 2015-16 data quantifying permaculture status across Chikwawa is hence only possible. 
Supplementary observations were made during our recent (June 2017) visits to the Kakoma area and meetings with various Water Point Committees (WPCs). Visits covered 33 gardens within 65 villages. That study focused upon WPC economic-financial arrangements. Nonetheless, observationalanecdotal data relevant to our agenda were obtained and are commented upon.

\section{Results}

Some contextual observations are initially presented to provide background to the main results that comprise: stakeholder interview findings, stagnant pond occurrence data and opportunity, permaculture economic-impact estimates, and recent observations of permaculture status. Examples of stagnant pond problems and permaculture practice encountered in the study area of varying success are illustrated in Fig. 2

\subsection{Contextual observations}

\subsubsection{Spilt water quantities}

The quantity of spilt water potentially available to permaculture projects was assessed by Schmalfuss (2014) for individual water points within the Timbenawo Group Village (Kakoma area of south-east Chapananga TA, Fig. 1). Daily abstraction over the $6 \mathrm{am}-6 \mathrm{pm}$ opening time was typically around 5,000 l/d for approximately 80 households served. Most water points exhibited a wastage rate of $20-30 \%$ of abstracted water over the day-long observations. However, the overall range was large at $11-80 \%$ and plausibly ascribed to water-quality influences. Increased wastage was equated to high salinity rendering the water unsuitable for drinking and used instead for washing. Conversely, low waste was tentatively equated to low salinity and associated high drinking-water value (Schmalfuss, 2014). Such observations may have implications for permaculture garden viability, with both water volume and quality (salinity) constraints possible.

\subsubsection{Water Point Committee (WPC) arrangements}

Management arrangements for rural water points centre around the inauguration of a Water Point Committee (WPC) responsible for borehole functionality, maintenance and finance (Hoko and Hertle, 2006; Government of Malawi - MIWD, 2010a). Malawian government guidelines stipulate all community-based operations and management should be voluntary and unpaid; community-based management is a cornerstone of rural Malawi. Hence all work on WPCs, overarching Water Users Association (WUA) and permaculture-garden related activities is voluntary. The purported theory of change is that if the WPC and the community see the benefit of the working garden and the 
maintained borehole, they are more willing to pay the lowered tariff (household charge for water use) arising and work towards sustaining it.

Each WPC has five to ten members elected democratically by the households served, or by the village chief based upon job aptitude. The WPC should have a gender balance (Government of Malawi - MIWD, 2010b). Communities are advised by NGOs on how to calculate tariffs (water charges) to household water-point users that cover life-cycle costs of maintenance, minor repairs, pump replacement as well as other civil works, and even possibly borehole replacement. WPC's are trained in financial management and the development of so-called 'water-point (borehole) banks' that were introduced to Chikwawa in 2015. Banks provide a community-based form of micro-lending that encourages community individuals to take out small 'micro-loans' (paid back monthly with interest) from borehole funds generated. Loans may help kick-start small businesses, or pay for other expenses. Water-point income thus comprises revenue from a tariff charge to household users of the water-point, late-payment fines, bank interest, interest on bank loans made and sales revenue from borehole garden produce. The WPC, in consultation with the community, need to decide whether permaculture should be adopted to help finance their water point.

A local Water Users Association (WUA) may potentially become involved and assume overarching responsibility for several water points and associated WPCs (Government of Malawi - MIWD, 2010a). This provides advantages of economy of scale to a WPC allowing increased capacity to absorb more expensive maintenance at short notice.

\subsubsection{Measures introduced over the study period}

Regulatory measures combating stagnant pond occurrence were introduced in 2013 (post our pond survey and main interview work) stipulating that newly drilled boreholes should install gravel-bed soakaways to drain excess water into the ground thereby reducing malaria risks. This requirement needs sufficient flexibility to accommodate permaculture irrigation of garden soils; this appears to be the case based on our experience of newly drilled sites.

\subsection{Stakeholder interview findings}

Key interview findings are summarised below primarily drawing upon our 2013 interviews (Halcrow, 2013) and supplemented by our 2014 work (Schmalfuss, 2014). An example interview mind-map summarising findings for Community Development Officers is shown in Fig. SM-1 (in the Supplementary Material). 
Agricultural Extension Workers (AEWs) had heard of (in 2013), but were unaware of the meaning of, permaculture. The Ministry of Agriculture already (unknown to interviewees) disseminated some permaculture information in their teaching on rain-water harvesting and kitchen gardens. Agricultural Development Officers (ADOs) were constrained by having only 55 rather than the 124 officers required to implement their responsibility to bring new skills and technology to small-scale farmers. Permaculture would be more feasible with capacity building. AEWs were unaware of ecofertiliser, but expressed interest due to its low cost (200MK/bag as opposed to $14,000 \mathrm{MK} / \mathrm{bag}$ ). Fertiliser is largely subsidised and adoption of eco-fertiliser could help alleviate subsidy needs (Dorward and Chirwa, 2011).

The Ministry of Education (MoE) acknowledged that wasted borehole water in schools often ended up in stagnant ponds and that permaculture would represent an elegant solution and learning opportunity. Pupils are taught about disease origin, including stagnant water hazards, and hence pond occurrence was acknowledged as counter-productive. They are also taught the basics of agriculture. Hence, with the attendant problems of wasted water and sanitation, interviewees agreed that interactive lessons in permaculture-garden maintenance could prove effective together with provision of nutritional food. Permaculture could be accommodated within NGO-led WASH and borehole curricula. Transition of childhood learning to adulthood awareness was considered a desirable prospective outcome.

Environmental Health Officers (EHOs) were very supportive of permaculture, but pinpointed that the imbalance of workload within a community often leads to confusion of ownership and eventual garden abandonment. A key conclusion is that gardens required a strong influence and leadership at the community level. The centrality of community-led total sanitation (CLTS), and associated capacity building, resulting in significantly increased health and sanitation provision in Chikwawa was recognised to provide potential momentum to permaculture promotion. Enhanced IWRM was noted to be a positive influence upon cross-organisational communication and collaboration.

Health Surveillance Assistants (HSAs) provided, or speculated upon, reasons for permaculture failure. These included borehole breakdown, poor performance of WPCs or chiefs, animals eating crops, an absence of strong steering, drought and flooding (notably 2015) and displaced effort during periods of famine and hunger. More positively, permaculture gardens were confirmed to 
produce food during droughts and could precipitate rapid repair of mal-functioning boreholes. HSAs emphasised that correct influence and centrality of WPCs were essential prerequisites to success.

Community Development Officers (CDOs) are highly involved in village communities and deliver teaching on preparation and operation of permaculture gardens (Fig. SM-1). They train communities on how to appoint to their WPCs. CDOs advise on the individual appointee responsible for the garden, but indicate improvements in that process could likely reduce garden failure rates. They recommended improved campaigning for permaculture and noted a critical factor in success was NGO conduct. Irresponsible NGOs failed to inform the government when installing boreholes. This resulted in follow-up training, including permaculture, not being provided and prospects of adoption becoming drastically reduced.

Villagers demonstrated a strong sense of community from which it is inferred that borehole gardens could be a success. Most are involved in growing food, and most appear willing to help in efforts benefitting the community. Where there have been successful gardens, villagers were happy not to waste water and pleased with their garden. Whole community involvement was typically manifest with appreciation that funding raised was primarily for water-point maintenance and that further spin-off benefit of a loan system may emerge. Regarding unsuccessful gardens, common problems described were animals eating crops, rotten fences and water-logging of crops. Villagers appreciated the critical need for correctly designed and sized gardens with an effective water distribution system that avoided manual watering (Fig. 2). The latter activity was, however, perceived frequent, but recognised as not ideal. Observations that gardens could often be ignored added credence to the opinion that permaculture required on-going driving influence by key, knowledgeable, individuals. Those interviewed without gardens admired neighbouring villages with gardens and wanted one.

Our companion survey of Schmalfuss (2014) elucidated further villager perspectives. Women involved in water-collection duties had already gained significant time savings as a consequence of the increased borehole density arising from the on-going drilling programme. Time savings were generally used for increased cleaning and recreation yielding improved sanitation and well-being, but interviewees were cognisant of the potential to invest in other community, or incomegenerating activities. A specific concern was hybrid seed prevalence was forcing communities to continuously buy new seed, rather than having native and hence re-plantable seed. Although more expensive, investment in native seeds was perceived to result in long-term financial savings and the potential to establish gardens as seed vault businesses. Villagers also suggested that significant flows 
into some gardens could allow greater areas of land for gardens, potentially bounded and protected by houses (noting however, proximity of household pit latrines to water points may be a confounding issue (Back et al., 2018)).

Village chiefs work alongside the government DCT for community betterment. They influence borehole placement and appointment of WPCs and recognise their mandate to undertake community responsibilities effectively to underpin permaculture success. Where there have been successful gardens, they emphasised the WPC was well appointed and communities worked together and were aware of the benefits, principally revenue to sustain the water point. Regarding unsuccessful gardens, they did not like the wasted water, but stressed that the community were often busy with other important activities, for instance field planting or harvesting. It was concurred that inter-village exchange programmes would likely prove valuable for the dissemination of good practice.

Entrepreneurs emphasised that eco-fertiliser use aligned with the ethos of permaculture, improved crop growth and was cheap (Mariwah and Drangert, 2011). Their business cornerstone was payment for a built latrine, or the first yield of eco-fertiliser as a sales commodity. They, however, emphasised the continued need for market development and the significant potential for an eco-fertilised borehole garden to make an ideal marketing show garden at a much frequented village location. There was potential benefit voiced to appointing entrepreneurs on WPCs as people responsible for permaculture gardens as their economic stimulus could drive garden success. Regarding villager responses to eco-fertiliser use (Schmalfuss, 2014) it was conjectured some interviewees could have presented positive views on its use rather than express a contrary view such as "not feeling comfortable about applying human manure as fertiliser to their gardens" due to it being perceived to jeopardise their existing NGO support. Whilst we view this perception as unfounded, reservations may be understandably widespread on the use of human faeces to fertilize gardens used for food production on social, religious and health-protection grounds.

The role of NGOs is recognised to be very varied and may depend upon the status of permaculture and associated water and sanitation hygiene (WASH) development and IWRM opportunity. NGOs aim to facilitate permaculture practical implementation, training needs and advocacy requirements. Their activity is viewed to be cross-cutting and integrative across the entire stakeholder range. In the present study area, Water For People - Malawi is the primary NGO facilitating activities. Key requirements have been to raise the awareness of permaculture and its benefits across the 
stakeholder range and mediating its practical implementation and training needs. For instance towards the end of 2011, permaculture became part of the sensitization process during borehole drilling campaigns. This was further developed into a design provided within the tender for drilling during the 2013 drilling programmes.

\subsection{Observed water point - stagnant pond occurrence}

The distribution of mapped groundwater points across Chikwawa and the subset with stagnant ponds is shown in Fig. 3. So-called 'Stagnant water points' failed to exhibit an obvious pattern of occurrence with points sometimes clustered, but also sporadic. A plausible relationship investigated was that of stagnant point proximity to rivers and wetlands arising from the increased probability of poorly drained lowland, or near-surface water tables, aiding pond formation. The percentage of total versus stagnant water-point occurrence in areas within $500 \mathrm{~m}$ of rivers was, respectively, $12.7 \%$ versus $11.8 \%$, and for wetlands, $9.3 \%$ versus $12.6 \%$. Hence river proximity is not construed to be a factor, nor is it likely that wetland proximity is significant. Supporting data were not available to assess other controls on pond formation that could include soil permeability, topography, presence of impermeable surfaces and villager care taken in avoiding water spillage (which may in turn depend upon water quality, notably salinity).

Stagnant water-point occurrence across individual TAs is summarised in Table 2. The percentage of stagnant occurrences of the total water points mapped is regarded as an under-estimate as not all water points were checked. Chikwawa contains 1894 water points (excluding Ndakwera TA's 172 water points not surveyed) of which $20.5 \%$ were stagnant. Adding the observed 86 stagnant water points that could not be correlated to the FLOW water-point database would raise the Chikwawa total occurrence to $25 \%$. For individual TAs, Maseya TA had the highest stagnant point occurrence at 43\% followed by adjoining TA Kasisi at $37.5 \%$. Together, these may hence form a priority geographic area for permaculture. The fourth highest is TA Katunga. Given its neighbouring proximity to both Maseya and Kasisi, there could be efficiencies gained in strategically targeting permaculture promotion and implementation across these three jurisdictions. Amalgamated stagnant points amounted to $36 \%$ of available water points, totalling 136 opportunities for borehole-garden permaculture. Strategic advantage would also arise as they occur in a relatively populated area around the District capital with main road networks and people movements aiding scheme visibility. 


\subsection{Scoping estimates of permaculture economic impact}

Scoping estimates are made below on the projected profitability of permaculture, including a basic sensitivity analysis.

\subsubsection{Opportunity and value}

Permaculture opportunity potentially available across Chikwawa is estimated by projection of the numbers of stagnant water points. Table 2 suggests that the percentage of stagnant versus total water points is $20 \%$ upwards, but sensitive to assumptions on the unknown number of points checked for stagnant water. Of the total 2065 well points (FLOW database at 2013), it is provisionally estimated that $50 \%$ were checked which gives rise to the 388 stagnant points observed representing a $37.6 \%$ occurrence rate. This reasonably compares to some individual TAs (Table 2). Applying this percentage to the unchecked borehole quota would amount to a further 388 permaculture opportunities. Including the phase of 1019 borehole installations imminent (in 2013) at a similar rate (recognising it would likely constitute a minimum) yields a further 383 prospective sites, thereby totalling 1159 borehole-garden permaculture projected opportunities. For an assumed nominal $10 \mathrm{~m}$ x $10 \mathrm{~m}$ garden area, the entire area for 1159 borehole gardens amounts to 116 ha.

Equally sub-dividing this area between seven common crops to provide a balanced diet and use of literature crop yields (FAOSTAT, 2013) allows estimation of a total annual yield for Chikwawa. An annual revenue estimate from permaculture produce sold is estimated by factoring in the market value for the garden crop produce (using everyday market values in Malawi). Table 3 indicates a borehole garden growing these seven crops would generate a garden-produce revenue of around $\$ 1440$ (US dollars) equivalent to MK480,000 (Malwai Kwacha) (for a 2013 exchange rate of 1MK = $0.003 \$$ (or $1 \$=333 \mathrm{MK}$ )). Operational costs for the garden and market sales additionally need to be annually met and are estimated at $\$ 500$ (Table SM-2). Subtracting the priority target item for income generation, the annual borehole maintenance fee of $\$ 540$, the potential annual profit is estimated at \$400. For a projected pan-Chikwawa, 1159 borehole garden 16-hectare area project, the annual profit amounts to $\$ 462,000$. On this basis, successful borehole gardens should provide more than enough funds for borehole maintenance.

\subsubsection{Investment opportunity}


Additional to the recurrent annual expenses and income projected (Table 3), garden setup requires capital investment. Based upon the construction of an actual Malawian permaculture garden, we estimate investment capital of around $\$ 3000$ (Table SM-3). With greater numbers of gardens and associated economies of scale, the capital cost per garden would be driven down.

Assuming profitability of $\$ 400$ per annum (Table 3), then the pay back on the $\$ 3000$ investment may be calculated as per Fig. 4a (ignoring interest, inflation, exchange rates). The investment would be repaid by 7.5 years and an overall return of $\$ 1000$ realised after 10 years. For the suggested target project area covering three TA's (136 gardens), the required investment would be $\$ 408,000$ with a return after a decade of $\$ 136,000$. Given the variability of garden efficiency and exchange rates, these numbers present a risk as a pure investment opportunity. However, corporate social responsibility may be a sufficient motivator for it to be viewed as a positive choice by some investors recognising the water-point sustainability and health security benefits realised.

Profitability may be enhanced by selecting the most profitable items of produce. Bananas, potatoes, tomatoes and cassava in equal ratio to maintain dietary variety increases annual sales revenue of a garden by $\$ 730$ to a net profit of $\$ 1130$ (after all expenses and borehole maintenance). At this profitability, Fig. 4b illustrates the investor would approach a return after just 2.75 years with a return over $\$ 8000$ by 10 years. Scaling up to a project of 136 functioning gardens across the combined three TA areas sees a return of \$1.13 million; a much more attractive investment opportunity.

\subsubsection{Sensitivity analysis}

Inflation in Malawi over 2001-17 averages at 15\% with a maximum of $38 \%$ occurring in February 2013 (http://www.tradingeconomics.com/malawi/inflation-cpi). Devalued currency arising may significantly influence profitability. Based on $30 \%$ differences either way, the calculated profit of $\$ 1130$ (Fig. 4b) would reduce to $\$ 791$ for a lower exchange rate of $1 \mathrm{MK}=\$ 0.0021$ and increase to $\$ 1470$ for an improved rate of $1 \mathrm{MK}=\$ 0.0039$. Returns on investment still occur in both cases at around 4 and 2 years respectively. Gardens would still make enough income to sustain water points. 
Profitability is reliant upon garden-permaculture efficiency which will vary due to soil conditions, adequate water distribution, weather influence, community engagement, expertise available. A garden at $50 \%$ efficiency will make a projected annual profit of just $\$ 45$. Perhaps just sustainable regarding water point maintenance, however, investment return at 67 years would be unsatisfactory. At $75 \%$ efficiency, the return at 5 years may well be satisfactory for an investor who wishes to have a positive impact. Using the optimal four crops and not allowing the efficiency to drop below $75 \%$, permaculture remains an intriguing opportunity. It is hence paramount to design gardens with space efficiency and agricultural knowhow to enable productivity that underpins economic sustainability alongside appropriate infrastructure to increase operational efficiency.

Growing-area size is fundamentally influential as revenue of produce sales approximately scale with area. Fig. 2 indicates gardens may be of quite variable size and possibly quite small. Schmalfuss (2014) observed fenced garden areas of just $36 \mathrm{~m}^{2}(6 \mathrm{~m}$ by $6 \mathrm{~m})$ to be quite prevalent in Timbenawo that would realise produce revenue perhaps $36 \%$ of the $100 \mathrm{~m}^{2}$ based estimates herein. Implementing the largest garden size technically feasible is considered a priority cognisant of water supply, soil conditions, community-input and land-ownership issues.

The numbers of permaculture opportunity across Chikwawa are influenced by assumptions made on the unknown proportion of boreholes checked for stagnant pond occurrence. Table SM-4 quantifies this sensitivity and illustrates for an assumed $30 \%$ check, a profit of just over $\$ 2 \mathrm{~m}$ is realised, This compares to just below $\$ 1 \mathrm{~m}$ for $70 \%$ checking. There is an undisputed need for better estimates of projected site availability to increase confidence in regional-scale investments required.

\subsection{Recent observations of permaculture status}

\subsubsection{Impact of promotional activity}

Follow-up observations in 2015 confirmed that IWRM promotional activities in Chapananga TA were worthwhile. WPCs were well established with $60 \%$ female representation, including significant decision-making positions. Permaculture gardens were present at $30 \%$ of water points and a waterpoint bank at $57 \%$ of points. A high proportion (98\%) of boreholes was functional with $72 \%$ having routine servicing. Communities had designed their tariff structure based upon full-cost recovery with support from government workers that had allowed inclusion of permaculture garden accounting and water-point banking in a transparent manner. Gardens had successfully achieved stagnant pond removal where this was the driver, generated income and water-point banking had successfully 
provided water users with opportunity to borrow start-up capital for small businesses. Around $14 \%$ of water users had received a loan with 33\% indicating it was used to buy fertilizer (likely for their household gardens) and the remainder used to buy food for the household. Loan access had hitherto been difficult, particularly for women. Tariff collection also appeared less problematic. Around 39\% of crops were sold to the water users thereby contributing to the food availability to the local waterpoint community with external sales forming the majority revenue.

Within the 18 villages evaluated, 57 water-point banks (one for each borehole) had raised \$8,035 (USD) in total over 1-2 years since inception (averaging \$141 per water point) with \$3793 raised from loans. These data indicate profitability and viability potential, rather than being a true indication of economic potential (and say comparison to Section 3.4 projections). Some selfreplication was also evident. The permaculture model had been emulated in some nearby villages. Thirteen Water-Point Banks had been formed without direct NGO or donor support.

\subsubsection{Regional permaculture uptake}

Borehole-garden permaculture uptake at $2015-16$ is seen to regionally vary across Chikwawa in relation to the opportunity afforded through the total 2067 water points available (Fig. 5). Permaculture implementations total 123 representing $6 \%$ of the mapped water points. Uptake is predominantly along the Mwanza Valley, especially in TA Chapananga where permaculture is employed at $26 \%$ of the 412 water points mapped (parts of this area were the focus of our IWRM promotional activity). Uptake, however, in other TA jurisdictions appears low with only sporadic occurrence and particularly low uptake in southern and more eastern areas. Comparison of Fig. 5 with the 2013 stagnant pond data (Fig. 3) suggests amelioration of stagnant pond occurrence is not an obvious driver of permaculture implementation, at least across the study area as a whole. The focused implementation predominantly derives from the recent borehole drilling programmes to improve water resource access. Incorporation of permaculture integral with water-point installation may hold particular advantage in that it should allow for optimal garden design and potential influence of borehole location to accommodate a well positioned garden (recognising precedence of other factors).

Retrofitting of existing water points with stagnant pond issues is apparent within the Mwanza valley area where there has been most intense permaculture activity (Fig. 5 inset). The plotted subset of 32 permaculture implementations undertaken at boreholes drilled before 2010 provides the best estimate of cases where retrofitting of existing water points with stagnant ponds is quite probable. 
These account for $26 \%$ of permaculture gardens, occurring at 2 boreholes drilled in the 1970s, 2 in the 1980 s, 10 in the 1990s, and 18 in the 2000s. These all occur in close proximity to new boreholepermaculture installations that is ascribed to the positive influence of that activity.

\subsubsection{Observations from site visits in 2017}

Follow-up observations made during our June 2017 visits to the Kakoma area revealed rather mixed results. Of the 65 villages visited, 33 had borehole gardens representing $51 \%$ occurrence. Of these, 13 were regarded by the participating community as successful. In terms of realised revenue, Lackson 4 reported a monthly produce revenue of around $\$ 75$ (representing $\$ 900$ annual) and Nkosa had an annual profit of around $\$ 300$ depending on the harvest (for $1 \mathrm{MK}=0.003 \$$ to compare to the Table 3 predicted annual revenue of $\$ 1440$, but recognising 2017 exchange rates were 0.0014 and actual dollar values are around 50\% less). Some 23 gardens, however, were regarded as underperforming, perhaps even 'failing'. Reasons given include animals destroying crops, poor community participation, theft of crops (especially cocoa), poor soil quality, and water quality (salinity) issues (most Fig. 2 photographs are from these visits and illustrate some of these points). Underperforming gardens could, however, still remain profitable despite their problems.

This continued mixed success highlights the continuing need for proactive support during and post implementation, particularly of agricultural and permaculture practice. Poorly conceived implementation was quite often apparent. Water distribution (furrows etc.) appeared inadequately considered and prone to evaporation, or local infiltration loss. Ground elevation could dictate runoff-drainage could not easily reach some crops. Crops could be haphazard, rather than planned around probable decreasing water availability with increased water-distribution distance. Gardens could be both under- and over-sized to water available. Manual watering (watering cans) or proactive pumping to provide irrigation water was sometimes apparent to overcome design shortfalls in achieving more passive water distribution and retention in soils. The inclusion of more sophisticated permaculture nuance design was generally not found. Communities blamed garden failings on the lack of provision of local technical support from government bodies.

Briefly regarding gender aspects, WPCs generally exhibited an equal gender ratio. Both men and women spent time managing and working in the garden. Women were mainly involved in selling the harvested garden produce with un-sold items typically being distributed among WPC families. Hence, benefit was being received for individual effort.

Briefly regarding eco-fertlilizer use, this appears to have not been taken forward to a significant degree, despite the enthusiasm apparent during our 2013 interviews. Certainly such practices 
require robust underpinning research to justify their acceptance as a proven technology alongside expert local advice ensuring eco-fertiliser use is appropriate (Ekane et al., 2016; Li et al., 2016; Singh, 2017). Given the high price of commercial fertilizer, and the permaculture ethos, gardens would need to source alternative animal waste, vegetation-based compost, organic rich-sediment from former stagnant ponds perhaps, to support garden-soil vitality.

\section{Strategic permaculture development}

\subsection{Summary of key issues}

Based on our results hitherto, we summarise key technical, economic, social and governance issues a strategic framework for effective permaculture development should seek to address:

- Adequate prioritisation of borehole-garden permaculture and recognition of its value

- Clarity in the roles and responsibilities of stakeholders and their interactions

- Realising and sustaining effective community ownership rather than disenfranchisement

- Expert permaculture training, coordination and adequate staffing of the multi-sector technical effort (Ministry, CDOs (NGOs)) for IWRM delivery and robust permaculture design

- Appropriate, policy and regulatory drivers, instruments and guidance

- Effective provision of education, training and support to enable a local community

- Appropriate formation, empowering and support of a leading water point committee

- Development of a garden design that truly invokes the permaculture ethos and nuances

- Securing of appropriate land for good permaculture design; managing land ownership issues

- Timely bespoke technical input, e.g. advice on garden design, irrigation, agriculture, finance

- Recognition and management of soil/water quality constraints upon garden performance

- Increased incentives for permaculture adoption retrofit of existing stagnant ponds

- Increased incentives for permaculture with newly drilled boreholes, e.g. contracted item

- On-going monitoring of project performance and provision of troubleshooting assistance

- Vulnerability and protection of gardens against climate conditions, events, animals, theft

- Improved prediction of permaculture profitability and securing investment mobilisation

- Optimal economic model: voluntary versus circular-economy - reward for individual effort

- Informed management and response to poor economic performance of gardens 
A lack of integrated consideration of the above issues may cause permaculture to under-perform, or even fail. Key inputs from the various stakeholders that may mitigate the above issues and substantially underpin a successful framework approach are considered below.

\subsection{Stakeholder roles}

\subsubsection{Government ministry inputs}

Overarching responsibility for District Development Plan (DDP) by the District Executive Committee (DEC) and implemented by their District Co-ordinating Team (DCT) is facilitated by monthly meetings of the component government ministries and area NGOs to discuss issues and align agenda efforts. Such vital information sharing aligns with National Water Policy (NWP) and efforts to promote IWRM (NWP, 2005). Synergistic management of water resources is a central policy. It may be contended, however, that the necessary structures are not fully in place to implement IWRM, including permaculture. This needs to be addressed. DCT meetings should increasingly serve as the high-level forum that facilitates the effective transfer of information and concerted integrative action necessary for IWRM. DEC members should proactively solicit funds to synergise operations and cross-sector training alongside enhanced project engagement with NGOs.

The Decentralisation Policy enacted in 1998 provides DEC with greater power to devolve to District level and better engage communities and is consistent with policy that encourages community water point management; it is directly relevant to permaculture (NWP, 2005). Gardens empower communities. Water demand management, within the NWP, requires more efficient water use and is consistent with the permaculture ethos. The significant alignment of permaculture with the NWP should provide the necessary policy impetus to underpin its success. It is imperative there is a consolidated effort, from all individual ministries, at all levels. This is a key requirement for Malawian permaculture in general advocated by Nordin and Nordin (2014).

The Ministry of Agriculture is regarded as linchpin in that technically appropriate agricultural approaches with efficient water use and crop choice are vital to garden efficiencies with bespoke garden input potentially vital. AEWs require necessary training in the nuances of sustainable permaculture design and practical implementation (Section 4.2.6) to allow them to relay its benefits to communities, or train others (NGOs, CDOs) advising communities. Agriculture is perceived technically best placed of the ministries to provide overall leadership on permaculture. A key issue in Malawi, however, is capacity. ADO under-staffing already results in efforts already being spread too thinly. 
The Ministry of Education critically shapes future generation thinking and should spearhead permaculture installations at schools with existing stagnant ponds and hence show-case implementation. Water supply, health, food and economic benefits, with demonstrable opportunities for taught hands-on practice, may be realised. Revenue generation may help alleviate tensions (evident in some interviews) arising between schools and communities over school boreholes that the community may currently contribute towards. Ministries of Health, Agriculture, Water and Education would ideally coordinate cross-sector implementation of permaculture educational programmes. Such an educational initiative may benefit from dedicated NGO influence that could facilitate and fund the teacher training and capacity building required.

The Ministry of Health is well placed to highlight the permaculture health-nutrition benefits. Their CLTS success illustrates the proven effectiveness of community-based learning where natural leaders from a community were selected to spread the word about unhygienic practices (Movik and Mehta, 2010). Communities strive for 'Open Defecation Free' status and may be rewarded with a borehole (pers. commun. Water For People, 2016). Such a grass-roots approach is regarded as a model community engagement lesson for establishing permaculture. Opportunities for alignment of CLTS with the permaculture agenda exist in relation to stagnant water filth and the social status in having a borehole garden. HSAs have invaluably contributed to the benchmark success of CLTS and may similarly convey permaculture health and sanitation issues to communities alongside targeted WPC training. Their eco-san facility experience allows them to be well placed to facilitate safeguarded integration of eco-fertiliser (Palamuleni, 2002). Likewise, local awareness of stagnant pool incidence puts them in a unique position to raise related health benefit awareness. They may also advise on nutritional needs and steer crop selection.

\subsubsection{NGO inputs}

NGOs ideally align themselves with government initiatives and optimally direct funding and effort for the betterment of the people. Their conduct is central to permaculture success (Swidler \& Watkins, 2009). It is imperative that NGOs provide mobilisation and coordinate integrated effort. Permaculture potential needs to be embraced and appropriately facilitated within NGO projects, with inputs spanning design and implementation, training and education, advocacy and policy. The advantages of promotion and proactive incorporation within drilling programmes (e.g., tender items) have been demonstrated herein and are critical. Likewise, the poor performance on an NGO 
may be equally critical and result in missed permaculture opportunity (Section 3.2). It is then incumbent upon DEC to enforce tighter controls.

A tension, as ever, is the degree of subsidised NGO involvement. The grass-roots approach to community development has generally shown progressive results as communities are empowered to control their own affairs and then prove capable of managing their society. NGO involvement is a crucial aspect of development to this position (Water for People, 2011). NGO involvement in permaculture must be well gauged, with proper training and direction of funds that allows communities to sustainably move away from a subsidised framework.

\subsubsection{Community Development Team (CDT) inputs}

CDTs are heavily involved in community development projects and should remain pivotal to permaculture uptake. They characterise the grass-roots involvement required for mobilisation, help empower communities in their own affairs instilling a development-oriented mentality. They assist the formation and training of WPCs and provide indispensable community teaching on maintaining their water resource within the CBMT. With time, this should evolve to increasingly experienced innovatory design additional to the standard garden design principals taught. Effecting the appropriate distribution of water is a critical failure point and expert advice bespoke to individual gardens perhaps necessary. CDTs should draw on soil science and hydro(geo)logical support from AEOs and NGOs where water distribution problems are evident as well as advice on soil or water quality issues and crop tolerances. A critical need to address is the provision of audited garden performance that may involve several years of evaluation to ensure a garden is sustainable. This may be challenging to provide in practice within development oriented organisations (moving on to new projects and areas) and probable area of weakness. It is recommended that the CBMT has built-in effective mechanisms that allow the WPCs to remain suitably empowered to proactively recognise problems and receive technical assistance with potential areas of failure, particularly during the critical garden establishment years or recovery from events, e.g. floods, theft.

\subsubsection{Community participation}

Permaculture will fail regardless if communities prove unwilling to maintain gardens. It is hence critical to discern how communities may be motivated and view the garden as a community resource. The entire community, by default, is responsible for the garden and therein potentially resides a key problem. Within an entirely voluntary setup, nobody is paid to maintain the garden. If some choose not to work, others may become aggrieved with the unfair workload and the garden is 
eventually abandoned. Without appropriate incentives and a dedicated influence, the failure rate of gardens may become high. Although contrary to the government ethos on community projects, the scenario raises the consideration as to whether alternative models are viable, notably with greater reward for individual efforts. These could be non-financial or in-kind benefits, for instance, receipt of reduced household water tariffs, low-interest rate loans, or a share of excess unsold food. A move to a more commercial 'circular economy' could be a critical factor in turning a garden failure to success and spin-out business activity. Emergent business initiatives were evident in our 2017 observations. One WPC was considered buying livestock which allowed the sales of milk and fertilizer (also used in the garden). Another significantly extended the area from the original vegetable/banana patch to cultivate tobacco sold locally providing funds for both the garden and water point.

Village chiefs are integral to the success of any community project, permaculture included, with power to direct peoples' efforts and prioritise projects (Kishindo, 2003). Prevailing attitudes may, however, dictate permaculture taking a reduced priority and support the need for promotional campaigns. Chiefs will directly influence permaculture in their participative selection of a WPC and their influence upon new borehole placement which should include appropriate landscape for permaculture. Facilitating organisations hence need to provide timely advice to chiefs and encouragements, e.g., involvement in community-exchange programmes on permaculture.

An effective WPC is vital to a sustained, funded, water-point and ensuring villagers are supplied with water. If the community decides to build a garden, then someone from the WPC will be appointed as responsible for its function, which means they have to encourage the necessary input from the people. With no real authority, this is a difficult, nonetheless critical, task. Strong reinforcement by proactive chiefs is realistically required to give gardens significant prospects of success. Wellappointed WPCs are doubtless essential for the success of permaculture and considered a priority area that CDTs support. A well trained WPC, and well informed chief, represent a significant step towards a viable garden. The overarching WUA may also be able to support the WPC through the aforementioned provision of economies of scale. Additionally, their experience base at existing water points with permaculture should prove useful.

\subsubsection{Entrepreneur inputs}

Entrepreneurs are often community members and can critically influence developing community economic self-sufficiency. They are often trained by NGOs and given the means to establish their own businesses, thereby fostering community economic empowerment. Whilst our focus has been 
on entrepreneurs associated with eco-fertiliser sale yielding permaculture ideals of waste water avoidance and organic matter re-use, other entrepreneurial opportunities may exist, e.g., fencing, seeds. Eco-fertiliser use reduces both garden investment and annual running costs and embraces sustainability and permaculture ideals. Community campaigns and teaching on eco-fertiliser safety and benefits are critical to increasing its use (Mariwah and Drangert, 2011). These require the technical backing of government health and agriculture sectors with science justification. The socioreligious concerns, however, are not insignificant and may indeed prevent significant adoption.

\subsubsection{Research interface and state-of-the-art technical training}

Permaculture is highly inter-disciplinary. A framework strategy for its increased deployment needs to embrace advances in agricultural practice, water distribution, soil science, (climate-change resistant) crop development alongside socio-economic developments that help sustain the water-point. A strategy needs to be kept 'live' by drawing upon research and state-of-the-art training. This can be provided in Malawi by indigenous organisations such as the Kusamala Institute of Agriculture and Ecology and the 'Never Ending Food' permaculture demonstration site and associated training centre focused upon permaculture and nutrition of national and international reach (http://www.neverendingfood.org; Nordin and Nordin, 2014). This is alongside effective drawdown of the growing international body of permaculture research. It is important that CDOs, AEWs and some NGO staff become trained in the ethos and nuance advantages of permaculture approaches in order they may provide targeted advice and ideas to communities on garden design and troubleshooting.

\subsection{Framework strategy}

\subsubsection{Conceptualised framework}

Strategising for implementation and sustainable management of borehole-garden permaculture is a perhaps surprisingly complex proposition that requires concerted alignment of the stakeholder inputs above. To this end a consolidated strategy is proposed schematically. Fig. 6 summarises the underpinning issues within a mind-map format. It highlights specific contextual issues, capabilities, opportunities and some of the recommended actions specific to stakeholders alongside key challenges to be overcome and potential benefits. Fig. 7 conceptualises the strategic framework proposed for borehole-garden permaculture development. Although illustration of nuance detail discussed above is not feasible, the figures aim to convey key aspects and be generically illustrative. 
Fig. 7 highlights the strategic actions and stakeholder integration necessary to embrace opportunity at this local-scale, water-food security, nexus. Inputs to the village community is illustrated at key organisational levels (NGOs, CDTs), together with individual inputs of key positions (HSAs, etc.). Some of the dynamic is illustrated, for example, the time-limited inputs of NGOs and CDTs. Monitoring of project performance is critical to these bodies to allow their timely withdrawal and realisation of the sustained community benefits highlighted within the 'community arrow'. The overarching governmental framework highlights the hierarchy involved, together with example linkages between bodies extolling the integration of actions required. The wide-ranging role of the NGO provides a facilitating core. Whilst the Malawian setup is voluntary based, we point to the possibility of alternative economic models within the NGO bullet point 'Problem solving - e.g., implementation of commercial - circular economy'. NGOs would be instrumental in achieving such a paradigm shift.

\subsubsection{Generalizability}

Consideration of the 'generalizability' of the framework elsewhere is pertinent. Inevitably some of the more specific approach detail may be coupled to institutional factors or scenarios inherent to the Chikwawa case. Our contention, however, is that the framework is generalizable. The key issues (Section 4.1) that the framework seeks to manage are essentially endemic, common across much of the developing world. Furthermore, similar counterpart stakeholder organisations invariably exist with comparable responsibilities to manage these issues. Whilst the applicability, or need, of borehole-garden permaculture will vary from locality to locality, nationally and internationally, the proposed framework should provide a basis for informed consideration and implementation of this option in most cases.

\section{Conclusions}

Borehole-garden permaculture makes sense for Malawi. There is sufficient alignment in policies calling for IWRM, improved sustainability of water, and community empowerment, to justify the adoption of a strategy intended to make permaculture work. Permaculture may provide funds to maintain water points, mitigate disease, use water that would otherwise be wasted and provide a perennial source of food, potentially during times of drought and hunger. It hence provides increased food security and resilience of water supply at an important local-scale nexus of waterfood need. Although the benefits are clear, its success hinges upon concerted actions being taken by adequately staffed governmental organisations, by NGOs and by the communities themselves. The 
current (2017) national vacancy rate (c. 60\%) in Ministry positions due to budgetary constraints represents a key on-going issue.

Our study of the Chikwawa District has identified key technical, economic, social and governance issues where effort should be concentrated. We highlight: the need for Improved bespoke technical input on garden design that invokes the permaculture ethos and its nuance advantages (e.g., optimal water distribution and conservation, vegetation distribution, composting); the recognition and management of soil/water quality issues; and, monitoring of project performance, including the provision of troubleshooting assistance. It is anticipated improvements in these may significantly improve garden performance. Proactive securing of permaculture retrofits of stagnant pond sites is also advocated via campaigns and incentives, especially in areas remote from the influence of drilling programmes. Community ownership of a project is a cornerstone requirement. However, it should be recognised alternative business models that permit greater reward for individual effort and, or development of spin-off entrepreneurial activity may make the difference, especially where community involvement has been problematic.

The framework proposed for more effective borehole-garden permaculture implementation and management advocates the integrated and aligned efforts of an array of stakeholders in order that the identified issues may be addressed in concert. The framework is considered generalizable to similar rural scenarios across the developing world due to the expected commonality of many of the underlying issues identified. Scoping calculations, together with recent field data, support permaculture gardens can be profitable. Gardens may provide the water-point maintenance funding sought and more; notably the underpinning of a water-point bank facilitating micro-loan access to a community. Despite its proven viability, borehole-garden permaculture remains susceptible to under-performance due to varying combinations of the identified issues. It is envisaged, however, that application of the proposed strategic framework, with bespoke local consideration of identified key issues arising, will help realise more successful permaculture project outcomes and move closer to achieving the full potential of rural water supply.

Where permaculture gardens are particularly successful, and land and water resources allow, it is foreseen that garden expansion to a larger community garden or small farmed area with purposeful abstraction, i.e., a small-irrigation scheme, may be an attractive option and, indeed, could yield significantly increased socioeconomic benefit. Such a scenario would be tending towards, for instance, the larger community garden(s), small-irrigation, schemes in Zimbabwe referred to earlier 
(Lovell et al., 1996; Waughway et al., 1998). The tension here, of course, is the sustainability of the proactive irrigation. Better, for an expanded garden - small farm community scheme, would be a thorough embracing of the permaculture ethos and tending towards the ideal of a 'dry land', not irrigated, scenario; an ideal admirably demonstrated, for instance, by the Aranya's Farm site in India (Aranya Agricultural Alternatives, 2017). Whilst the spilt borehole grey-water use proposed herein is valuable, the Aranya site, and others, reinforce that this still represents a small portion of the permaculture opportunity open to rural village communities. Future research, and application, should look to underpin realisation of this greater permaculture opportunity.

\section{Acknowledgments}

We gratefully acknowledge the funding of this research by the Scottish Government under the Scottish Government Climate Justice Fund Water Futures Programme research grant awarded to the University of Strathclyde (R. Kalin). The logistical support of the District of Chikwawa and the Malawi Ministry of Agriculture, Irrigation and Water Development together with the proactive participation of the village communities across the District of Chikwawa studied is gratefully acknowledged. Photo credit for some of the graphical abstract content goes to Laura McGrath.

\section{Appendix A. Supplementary data}

Supplementary data to this article (the referred to Supplementary Material (SM)) can be found online at http://dx.doi.org/journal to provide

\section{References}

ActionAid, 2006. Climate change and smallholder farmers in Malawi - Understanding poor people's experiences in climate change adaptation. ActionAid International, London. https://www.actionaid.org.uk/sites/default/files/doc lib/malawi climate change report.pdf

Akhtar, F., Lodhi, S.A., Khan, S.S., Sarwar, F., 2016. Incorporating permaculture and strategic management for sustainable ecological resource management. Journal of Environmental Management, 179, 31-37. http://doi.org/10.1016/i.jenvman.2016.04.051

Aranya Agricultural Alternatives, 2017. Aranya's Farm. http://permacultureindia.org/permaculturefarms/ [accessed 28 Oct. 2017]. 
Back, J.O., Rivett, M.O., Hinz, L.B., Mackay, N., Wanangwa, G.J., Phiri, O.L., Songolo, C.E., Thomas, M.A.S., Kumwenda, S., Nhlema, M., Miller, A.V.M., Kalin, R.M., 2018. Risk assessment to groundwater of pit latrine rural sanitation policy in developing country settings. Science of the Total Environment. 613-614C, 592-610. https://doi.org/10.1016/j.scitotenv.2017.09.071

Birnbaum, J., Fox, L., 2014. Sustainable [r]evolution: Permaculture in ecovillages, urban farms, and communities worldwide. 368 pp. North Atlantic Books, Berkeley, CA: ISBN: 9781583946480

Bryman, A., 2012. Social research methods (4 ${ }^{\text {th }}$ Ed.). New York: Oxford University Press Inc.

Bradley, L., 2014. The Spreading of the Permaculture Revolution in Northern Central Tanzania, and Beyond... The Permaculture Research Institute. https://permaculturenews.org/2014/08/11/spreading-permaculture-revolution-northern-centraltanzania-beyond/ [accessed 17 May 2017].

Branca, G., Paolantonio, A., Grewer, U., Cavatassi, R., Longwe, A., Cattaneo, A., Vetter, S., Lipper , L., 2016. Linking food security, climate change adaptation and mitigation: the case of sustainable land management in Malawi. Rivista di Economia Agraria, Anno LXXI, n. 1 (Supplemento), Proccedings of the $52^{\text {nd }}$ SIDEA Conference, 521-532. http://dx.doi.org/10.13128/REA-18669

Chiweza, A.L., 2010. A review of the Malawian decentralisation process: Lessons from selected Districts. The Ministry of Local Government and Rural Development. http://www.ndr.mw:8080/xmlui/handle/123456789/401

Dorward, A., Chirwa, E., 2011. The Malawi agricultural input subsidy programme: 2005/06 to 2008/09. International Journal of Agricultural Sustainability, 9(1), 232-247. http://dx.doi.org/10.3763/ijas.2010.0567

Ecological Society of America, 2011 Standing water and mosquito breeding in cities. www.sciencedaily.com/releases/2011/08/110812091524.htm [accessed 17 May 2017].

Ekane, N., Mertz, C.K., Slovic, P., Kjellén, M., Westlund, H., 2016. Risk and benefit judgment of excreta as fertilizer in agriculture: An exploratory investigation in Rwanda and Uganda. Human and Ecological Risk Assessment: An International Journal, 22(3), 639-666.

http://dx.doi.org/10.1080/10807039.2015.1100515

Ellis, F., Manda, E., 2012. Seasonal food crises and policy responses: A narrative account of three food security crises in Malawi. World Development, 40(7), 1407-14. http://doi.org/10.1016/j.worlddev.2012.03.005

FAOSTAT, 2013. Food and Agriculture Organization (FAO) of the United Nations - FAOSTAT Online database http://faostat.fao.org/site/666/default.aspx [accessed 30 July 2013].

Government of Malawi - MIWD (Ministry of Irrigation and Water Development), 2010a. Guidelines for the establishment of Water Users Association in Malawi. Market centre and rural piped water supply and sanitation programme. Government of Malawi, Lilongwe. http://wesnetwork.org.mw/Documents/Manuals/GWSS3 Guidelines for Establishment of WUA.pdf 
Government of Malawi - MIWD (Ministry of Irrigation and Water Development), 2010b. Implementation guidelines for rural water supply and sanitation. Government of Malawi, Lilongwe. http://www.wesnetwork.org.mw/Documents/Manuals/G-

4 Implementation\%20Guidelines\%20for\%20RWSS July\%202010\%20(Final\%20ver).pdf

Greenblott, K., Nordin, K., 2012. Permaculture design for orphans and vulnerable children programming: Low-cost, sustainable solutions for food and nutrition insecure communities, AIDS Support and Technical Assistance Resources, AIDSTAR-One (Task Order 1), Arlington, VA: USAID

Halcrow, A., 2013. Strategizing for permaculture in Chikwawa, Malawi. MSc Environmental Engineering thesis (unpublished), Department of Civil and Environmental Engineering, University of Strathclyde.

Hemenwey, T., 2015. The Permaculture City: Regenerative Design for Urban, Suburban, and Town Resilience. Chelsea Green Publishing, 288 pp. http://www.chelseagreen.com/the-permaculture-city

Hoko, Z., Hertle, J., 2006. An evaluation of the sustainability of a rural water rehabilitation project in Zimbabwe. Physics and Chemistry of the Earth, 31(15-16), 699-706. http://doi.org/10.1016/i.pce.2006.08.038

Holmgren, D., 2002. Permaculture - Principles and pathways beyond sustainability. East Meon, Hampshire: Permanant Publications.

Holmgren Design, 2017. Holmgen Design: Permaculture design and innovation. https://holmgren.com.au/about-permaculture/?v=3a1ed7090bfa _accessed 24 March 2017]

Hussein, M.K., 2003. The role of Malawian local government in community development. Development Southern Africa, 20(2), 271-282. http://dx.doi.org/10.1080/03768350302960

Kishindo, P., 2003. Community development in Malawi: Experiences at the grassroots. Development in Practice, 13(4), 380-387. http://www.jstor.org/stable/4029662

Li, Q., Wang, X. and Shi, H., 2016. The Evaluation of Small Scale Composting of Human Feces for Household Application. Journal of Water Sustainability, 6(4), 113-124. http://www.jwsponline.com/uploadpic/Magazine/pp113-124\%20JWS-A-16-008.pdf

Lovell, C.J., Batchelor, C.H., Waughray, D.K., Semple, A.J., Mazhangara, E., Mtetwa, G., Murata, M., Brown, M.W., Dube, T., Thompson, D.M., Chilton, P.J., Macdonald, D.M.J., Conyers, D., Mugweni, O., 1996. Small scale irrigation using collector wells pilot project - Zimbabwe. Final report October 1992 - January 1996. Wallingford, Institute of Hydrology, IH Report ODA 95/14, 106pp. http://nora.nerc.ac.uk/id/eprint/3946

Mancebo, C.E., De la Fuente de Val, G., 2016. Permaculture, a tool for adaptation to climate change in the communities of the Laguna Oca Biosphere Reserve, Argentina. Procedia Environmental Sciences, 34, 62-69. https://doi.org/10.1016/j.proenv.2016.04.006

Mariwah, S., Drangert, J.O., 2011. Community perceptions of human excreta as fertilizer in periurban agriculture in Ghana. Waste Manage Res 29(8), 815-822. http://dx.doi.org/10.1177/0734242X10390073 
Movik, S., Mehta, L., 2010. The dynamics and sustainability of community-led total sanitation (CLTS): Mapping challenges and pathways. The STEPS Centre, Institute of Development Studies and SPRU Science and Technology Policy Research, University of Sussex, UK. https://www.ids.ac.uk/files/dmfile/CLTSweb.pdf

Mulwafu, W., Chipeta, C., Chavula, G., Ferguson, A., Nkhoma, B.G., Chilima, G., 2003. Water demand management in Malawi: problems and prospects for its promotion. Physics and Chemistry of The Earth, 28(20-27), 787-796. http://doi.org/10.1016/j.pce.2003.08.003

Mulwafu, W.O., Msosa, H.K., 2005. IWRM and poverty reduction in Malawi: A socioeconomic analysis. Physics and Chemistry of the Earth, 30, 961-967. http://doi.org/10.1016/j.pce.2005.08.043

Nordin, K., Nordin, S., 2014. Never ending food in Malawi. Alliance for Food Sovereignty in Africa (AFSA) - Agroecology case study. http://afsafrica.org/wp-content/uploads/2015/11/Never-EndingFood-in-Malawi.pdf

NWP (National Water Policy), 2005. Lilongwe: Ministry of Irrigation and Water Development.

Palamuleni, L. G., 2002. Effect of sanitation facilities, domestic solid waste disposal and hygiene practices on water quality in Malawi's urban poor areas: a case study of South Lunzu Township in the city of Blantyre. Physics and Chemistry of The Earth, 27(11-22), 845-850. http://doi.org/10.1016/S1474-7065(02)00079-7

Pavelic, P.; Giordano, M.; Keraita, B.; Ramesh, V; Rao, T. (Eds.). 2012. Groundwater availability and use in Sub-Saharan Africa: A review of 15 countries. Colombo, Sri Lanka: International Water Management Institute (IWMI). 274 p. http://dx.doi.org/10.5337/2012.213

Schmalfuss, J., 2014. Practical application of integrated water resources management in the Chikwawa District, Malawi - An economic and social evaluation of locally available resources. MSc Master of Science in Sustainability \& Environmental Studies thesis (unpublished), Department of Civil and Environmental Engineering, University of Strathclyde.

Singh, S., Mohan, R.R., Rathi, S., Raju, N.J., 2017. Technology options for faecal sludge management in developing countries: Benefits and revenue from reuse. Environmental Technology \& Innovation, 7, 203-218. https://doi.org/10.1016/j.eti.2017.02.004

Smith-Carrington, A.K., Chilton, P.J., 1983. Groundwater Resources of Malawi. Overseas Development Administration Institute of Geological Sciences.

http://resources.bgs.ac.uk/sadcreports/malawi1983smithcarringtonmalawigwresources.pdf

Stark, J., 2011. Mwanayaya Village: A feasibility study of a gravel bed reservoir and an Insight into the adoption of permaculture. MSc Environmental Engineering thesis (unpublished), Department of Civil and Environmental Engineering, University of Strathclyde.

Swidler, A., Watkins, S.C., 2009. "Teach a man to fish": The Doctrine of Sustainability and Its Effects on Three Strata of Malawian Society. World Development, 37(7), 1182-96. http://doi.org/10.1016/i.worlddev.2008.11.002

UN (United Nations), 2014. News on Millennium Development Goals, www.un.org/millenniumgoals [accessed 10/08/2014] 
UN CfDP (United Nations Committee for Policy Development), 2016. List of Least Developed Countries (as of may 2016) http://www.un.org/en/development/desa/policy/cdp/ldc/ldc list.pdf

Van Den Broek, M., Brown, J., 2015. Blueprint for breakdown? Community Based Management of rural groundwater in Uganda. Geoforum, 67, 51-63. http://doi.org/10.1016/i.geoforum.2015.10.009

Vidal, J., 2016. I was so hungry I ate water lilies: southern Africa's food crisis in a dozen dishes. The Guardian, 17 December 2016. https://www.theguardian.com/globaldevelopment/2016/dec/17/hungry-ate-water-lilies-southern-africa-food-crisis-dozen-dishes-cropfailure-drought-john-vidal [accessed $20 \mathrm{Jul} 2017$ ]

Vitari, C., David, C., 2017. Sustainable management models: innovating through permaculture. Journal of Management Development, 36(1), 14-36. http://doi.org/10.1108/JMD-10-2014-0121

Water Aid, 2013. Hand pumps. Water Aid Technical Brief. www.wateraid.org/technologies

Water for People, 2011. Malawi Annual Report, Blantyre: Water for People - Malawi https://www.waterforpeople.org/country-pages/malawi

Water for People, 2013. Online water map available at: http://watermapmonitordev.appspot.com/ [Accessed 20 Aug 2013].

Waughray, D.K., Lovell, C.J., Mazhangara, E., 1998. Developing basement aquifers to generate economic benefits: a case study from Southeast Zimbabwe. World Development 20(10), 1903-12. https://doi.org/10.1016/S0305-750X(98)00086-2 


\section{Tables}

Table 1. Description of stakeholders interviewed.

\begin{tabular}{|l|l|}
\hline Interviewee & Description \\
\hline $\begin{array}{l}\text { Agricultural Extension } \\
\text { Workers (AEWs) }\end{array}$ & $\begin{array}{l}\text { Responsible for national policy interpretation and the sustainability of } \\
\text { agriculture. They bring new skills and technology to farmers. }\end{array}$ \\
\hline The Ministry of Education & $\begin{array}{l}\text { Responsible for children's education. They select and facilitate the } \\
\text { undertaking of school educational programmes and collaborate on the } \\
\text { installation of WASH (water and sanitation hygiene) and borehole } \\
\text { drilling programmes. }\end{array}$ \\
\hline $\begin{array}{l}\text { Environmental Health } \\
\text { Officers (EHOs) }\end{array}$ & $\begin{array}{l}\text { There are six EHOs in Chikwawa, each responsible for one TA and co- } \\
\text { ordinating HSAs in their effort to improve health and sanitation. }\end{array}$ \\
\hline $\begin{array}{l}\text { Health Surveillance } \\
\text { Asstants (HSAs) }\end{array}$ & $\begin{array}{l}\text { Provide the community level involvement of The Ministry of Health } \\
\text { responsible for teaching about health \& sanitation issues in villages and } \\
\text { provide monitoring and supervision in WASH programmes. }\end{array}$ \\
\hline Officers (CDOS) & $\begin{array}{l}\text { Involved in communities at the grass-roots level. They facilitate } \\
\text { community development projects and provide important training for } \\
\text { villagers to empower them in different ways. }\end{array}$ \\
\hline Villagers & $\begin{array}{l}\text { Citizens of Chikwawa. The work of all other stakeholders is designed to } \\
\text { improve various aspects of their lives. }\end{array}$ \\
\hline Chiefs & $\begin{array}{l}\text { Each village has a chief in charge of directing villager efforts. They make } \\
\text { important decisions on the community's behalf and influence the } \\
\text { implementation of village projects. }\end{array}$ \\
\hline Entrepreneurs & $\begin{array}{l}\text { These entrepreneurs are involved in the eco-san latrine construction } \\
\text { business and harvest eco-fertiliser from latrines for sale. }\end{array}$ \\
\hline $\begin{array}{l}\text { Non-governmental } \\
\text { organisations (NGOs) }\end{array}$ & $\begin{array}{l}\text { NGOs - nonprofit entities independent of governmental influence that } \\
\text { aim to facilitate community development and wellbeing via projects } \\
\text { typically funded from international aid. Water For People - Malawi were } \\
\text { the primary NGO participant in the study. }\end{array}$ \\
\hline
\end{tabular}


Table 2. Occurrence of water points for groundwater supply and the percentage of these with stagnant water observed in Chikwawa and its component Traditional Authorities (Ndakwera TA had 171 water points but no data on stagnant water point occurrences and was excluded).

\begin{tabular}{|l|c|c|c|}
\hline $\begin{array}{l}\text { Traditional } \\
\text { Authority }\end{array}$ & Total Water Points & $\begin{array}{c}\text { Stagnant Water } \\
\text { Points }\end{array}$ & $\begin{array}{c}\text { \% Stagnant Water } \\
\text { Points }\end{array}$ \\
\hline Ngabu & 529 & 90 & 17.0 \\
\hline Mululima & 56 & 18 & 32.1 \\
\hline Maseya & 128 & 55 & 43.0 \\
\hline Masache & 69 & 10 & 14.5 \\
\hline Makhwira & 314 & 73 & 22.9 \\
\hline Lundu & 258 & 26 & 10.1 \\
\hline Katunga & 134 & 36 & 26.9 \\
\hline Kasisi & 120 & 45 & 37.5 \\
\hline Chapananga & 250 & 31 & 12.4 \\
\hline Ngowe & 36 & 4 & 11.1 \\
\hline & & & \\
Total for Chikwawa & 1894 & 388 & 20.5 \\
\hline
\end{tabular}


Table 3. Estimated food production and economic value for 16.6 ha of land (1159 gardens) growing equal proportions of the seven crops listed for Chikwawa (assuming $1 \mathrm{MK}$ (Malawi Kwacha) is 0.003 $\$$ (US dollar); 1 tonne $(\mathrm{t})=1000 \mathrm{~kg} ; 1 \mathrm{ha}=10,000 \mathrm{~m}^{2}$ ).

\begin{tabular}{|c|c|c|c|c|c|}
\hline Crop & $\begin{array}{l}\text { Yield per } \\
\text { hectare } \\
\mathrm{t} \mathrm{ha}^{-1} \mathrm{yr}^{-1}\end{array}$ & $\begin{array}{c}\text { Chikwawa } \\
\text { Annual yield } \\
\text { t yr }\end{array}$ & $\begin{array}{l}\text { Market value } \\
\text { of crop } \\
\$ \mathrm{~kg}^{-1}\end{array}$ & $\begin{array}{c}\text { Chikwawa Annual } \\
\text { value } \\
\$\end{array}$ & $\begin{array}{c}\text { Garden annual } \\
\text { value } \\
\$\end{array}$ \\
\hline Banana & 26.2 & 433 & 1.50 & 649,500 & 560 \\
\hline Potato & 17.1 & 283 & 0.90 & 254,700 & 220 \\
\hline Tomato & 8.90 & 147 & 1.80 & 264,000 & 228 \\
\hline Groundnut & 1.05 & 17.3 & 1.95 & 33,735 & 29 \\
\hline Cassava & 21.5 & 357 & 0.75 & 267,750 & 231 \\
\hline Pidgeon peas & 1.03 & 17.0 & 1.50 & 25,500 & 22 \\
\hline Plantains & 9.98 & 165 & 1.05 & 173,250 & 149 \\
\hline \multicolumn{4}{|c|}{ Permaculture garden produce sales - annual income } & $1,668,000$ & 1440 \\
\hline \multicolumn{4}{|c|}{ Borehole maintenance - annual costs } & 626,000 & 540 \\
\hline \multicolumn{4}{|c|}{ Permaculture garden / sales operational - annual costs } & 580,000 & 500 \\
\hline \multicolumn{4}{|r|}{ Annual profit } & 462,000 & 400 \\
\hline
\end{tabular}




\section{Figure captions}

Fig. 1. Chikwawa District study area show in the Traditional Authority (TA) jurisdictions and locality of the Timbenawo Group Village against a backdrop of topography and surface-water drainage.

Fig. 2. Photographs showing: (a) excessive spilt groundwater surrounding wellhead; (b) engineered drainage of spilt groundwater away from wellhead; (c) stagnant pond with easy access for free roaming livestock; (d) poor soakaway leading to pond accumulation beyond and probable mosquito breeding area; (e) successful garden showing cold - dry season crops growing well - soakaway at end of drainage channel primarily irrigates banana trees (adjacent to former hand-washing concrete stand), however, remaining garden is irrigated by water collected from the borehole in watering cans - still, this garden is very successful and reports good revenue; $(f, g)$ successful gardens (early growing season) showing water drainage to garden and distribution throughout via furrow irrigation channels; (h) functional garden but pond in garden dug out deliberately to collect wasted water used in watering cans for irrigation - hence defeats the ideal of natural runoff irrigation and mosquito-related health risks remain; (i) failed permaculture showing poor drainage in the garden and stagnant pond spread outside garden perimeter; (j) permaculture garden in disrepair - stagnant pond within the garden, broken fence allowing livestock entry, waste and rubbish thrown in the garden (photo credits: J. Truslove, excepting a) due to M. Nhlema).

Fig. 3. Distribution of groundwater supply boreholes (water points) in Chikwawa and subset with stagnant ponds identified by HSAs (2013 data).

Fig. 4. Return on a capital investment of $\$ 3000$ for a borehole permaculture garden that realises (a) $\$ 400$ annual profit and (b) $\$ 1130$ profit achieved by growing more profitable produce.

Fig. 5. Permaculture borehole gardens in Chikwawa observed in 2015 - 2016 shown relative to all groundwater points. The subset of 32 permaculture occurrences located at boreholes drilled before 2010 are likely to have involved the retrofit of a stagnant pond issue (see main text for detail).

Fig. 6. Borehole-garden permaculture development strategy for the Chikwawa District displayed as a mind-map. 
Fig. 7. Borehole - garden permaculture strategic development framework. Governmental bodies are indicated by the black coloration, NGOs by blue, and the community and related bodies by redorange (inset photo credit: J. Schmalfuss). 
Fig.ure 1.

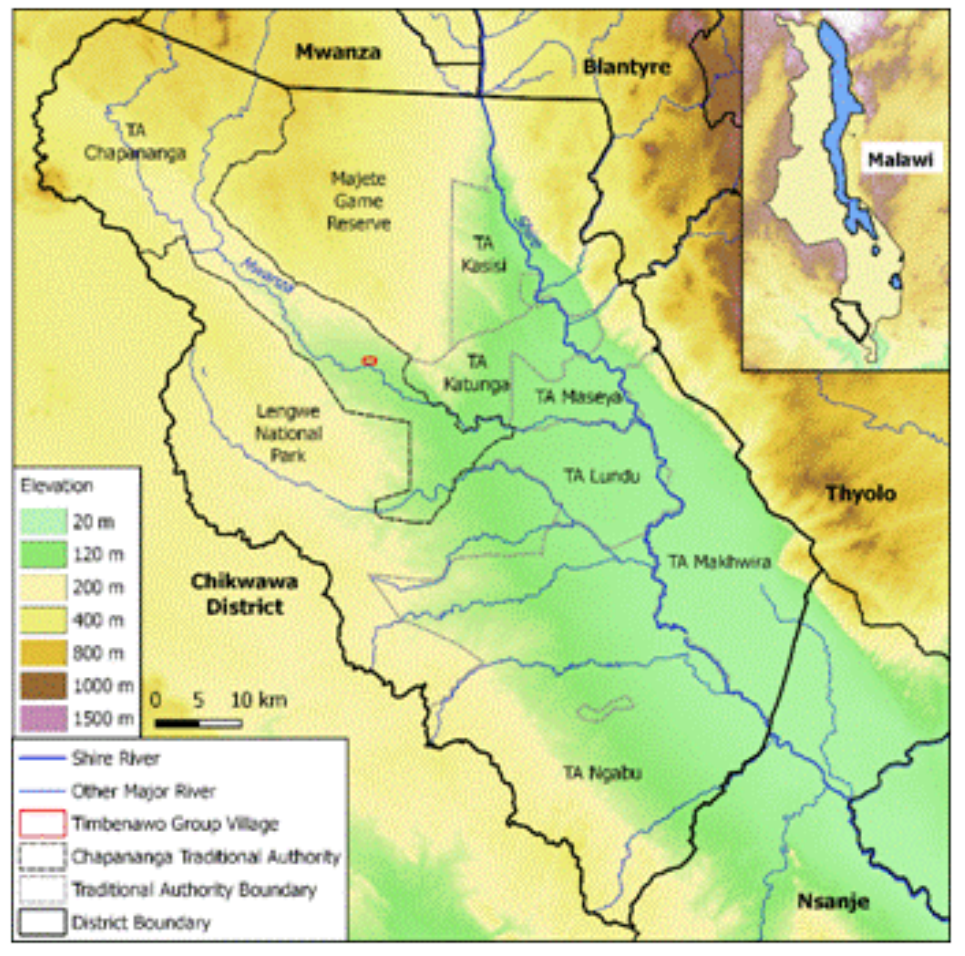


Figure 2.

(a)

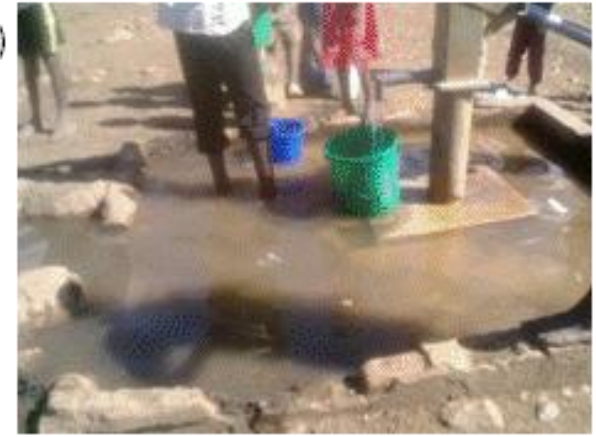

(c)

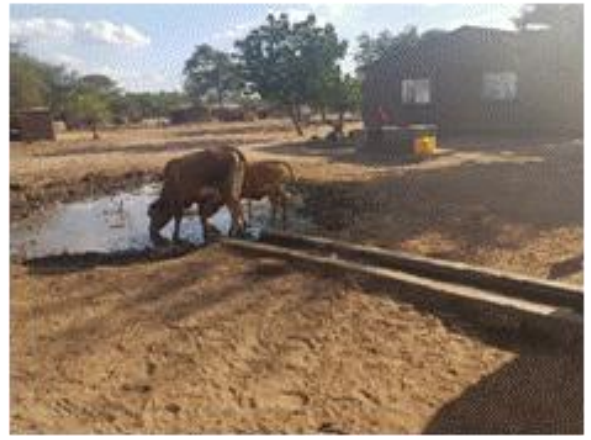

(e)

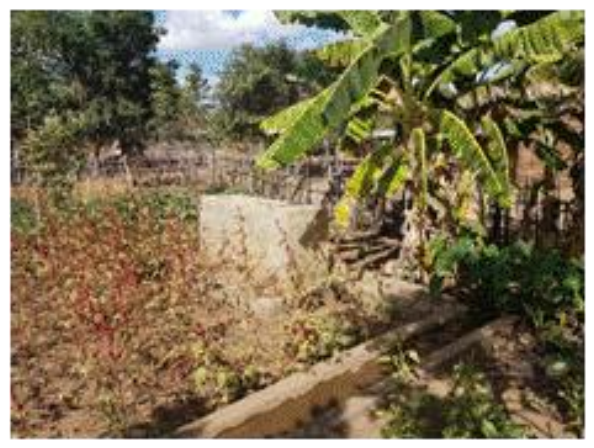

(g)

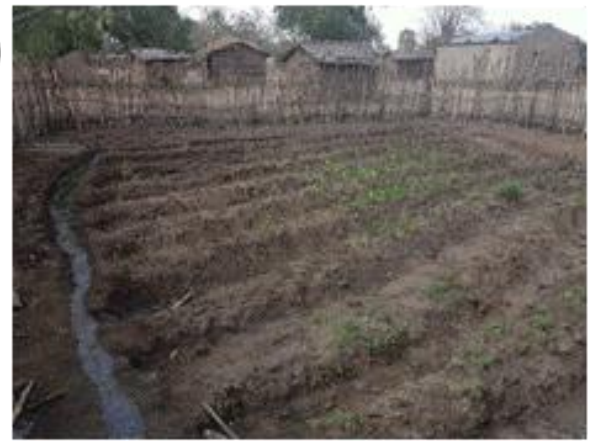

(i)

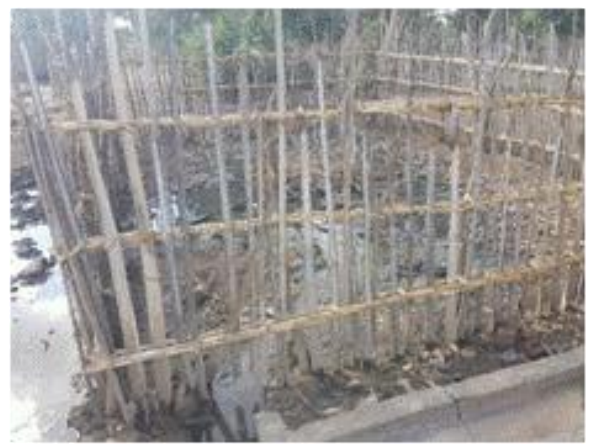

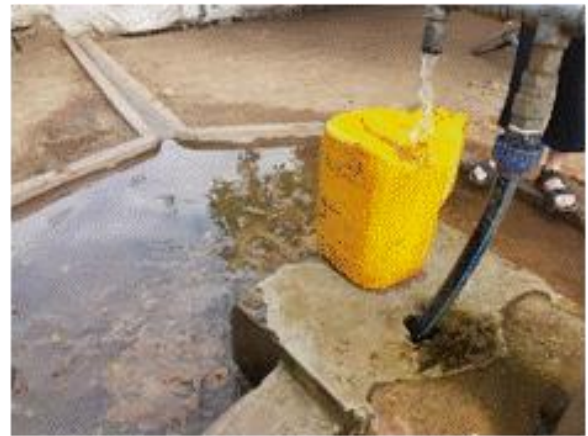

(b)

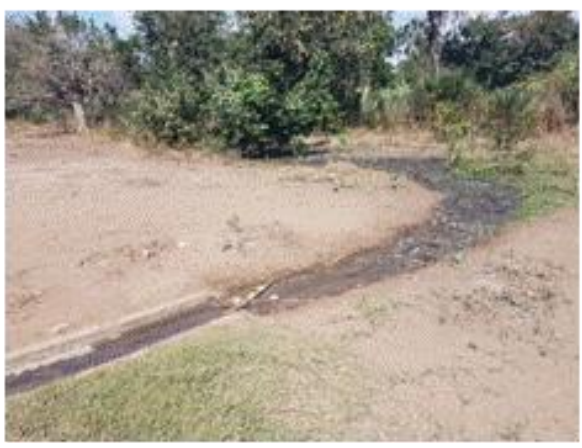

(d)
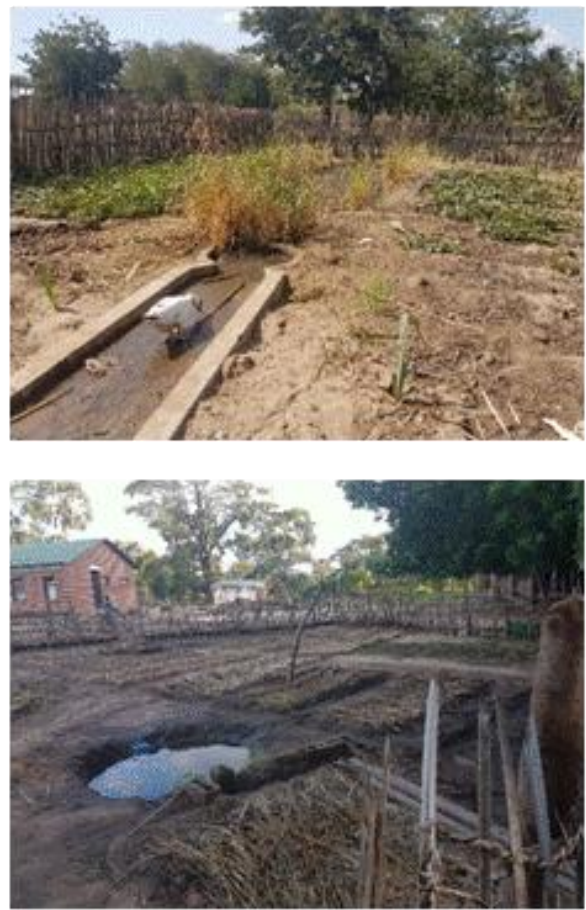

(h)

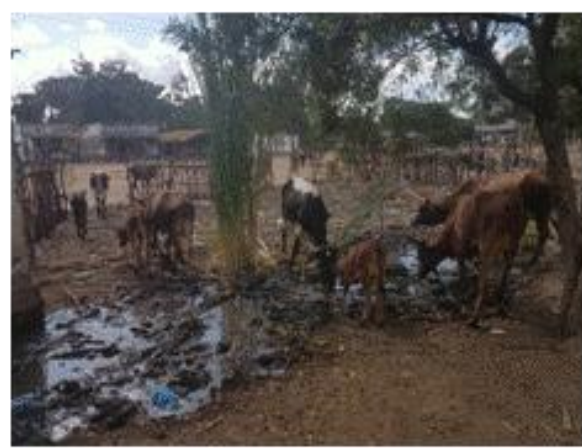

(j) 
Figure 3.

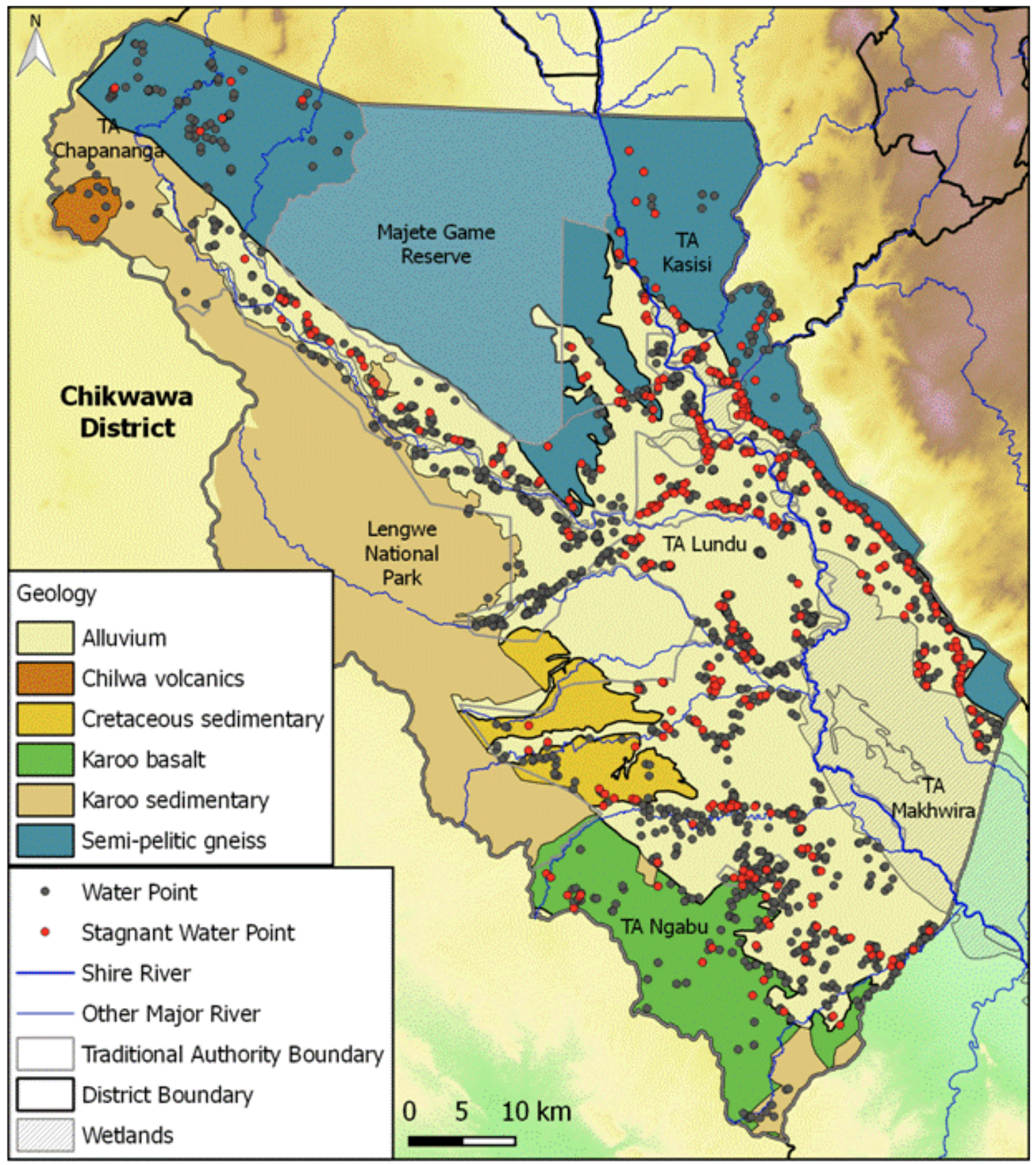


Figure 4.
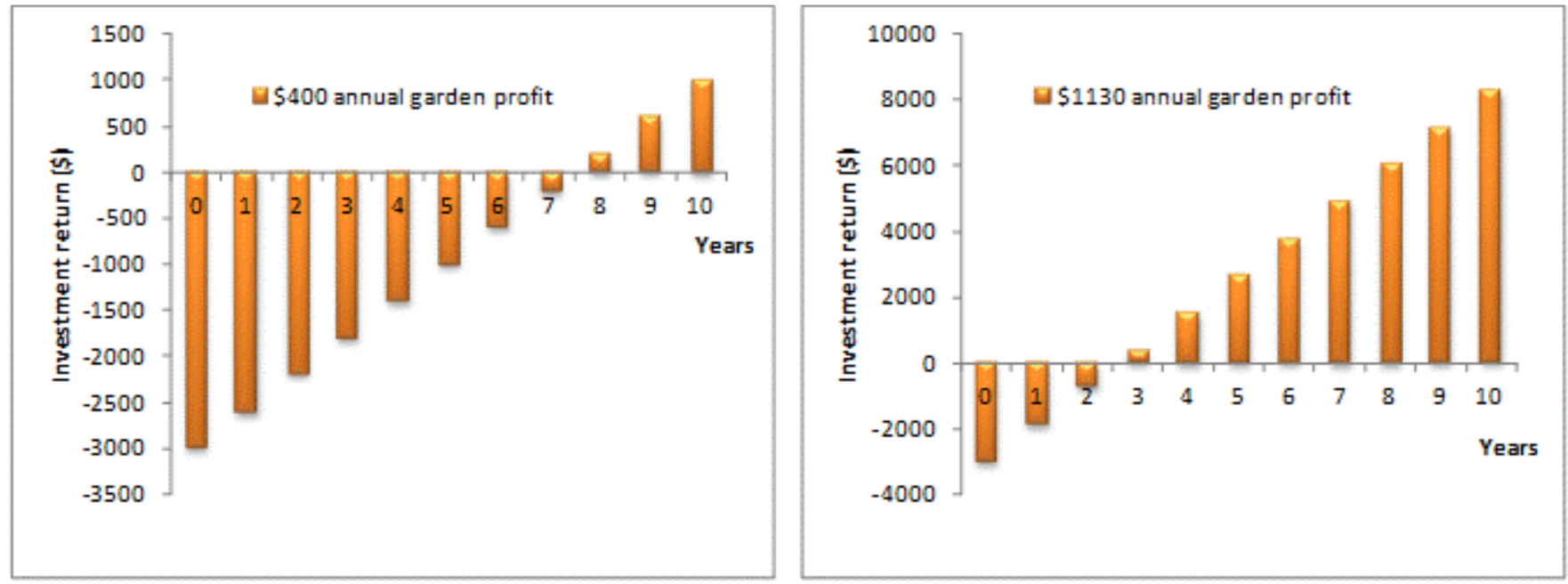
Figure 5.

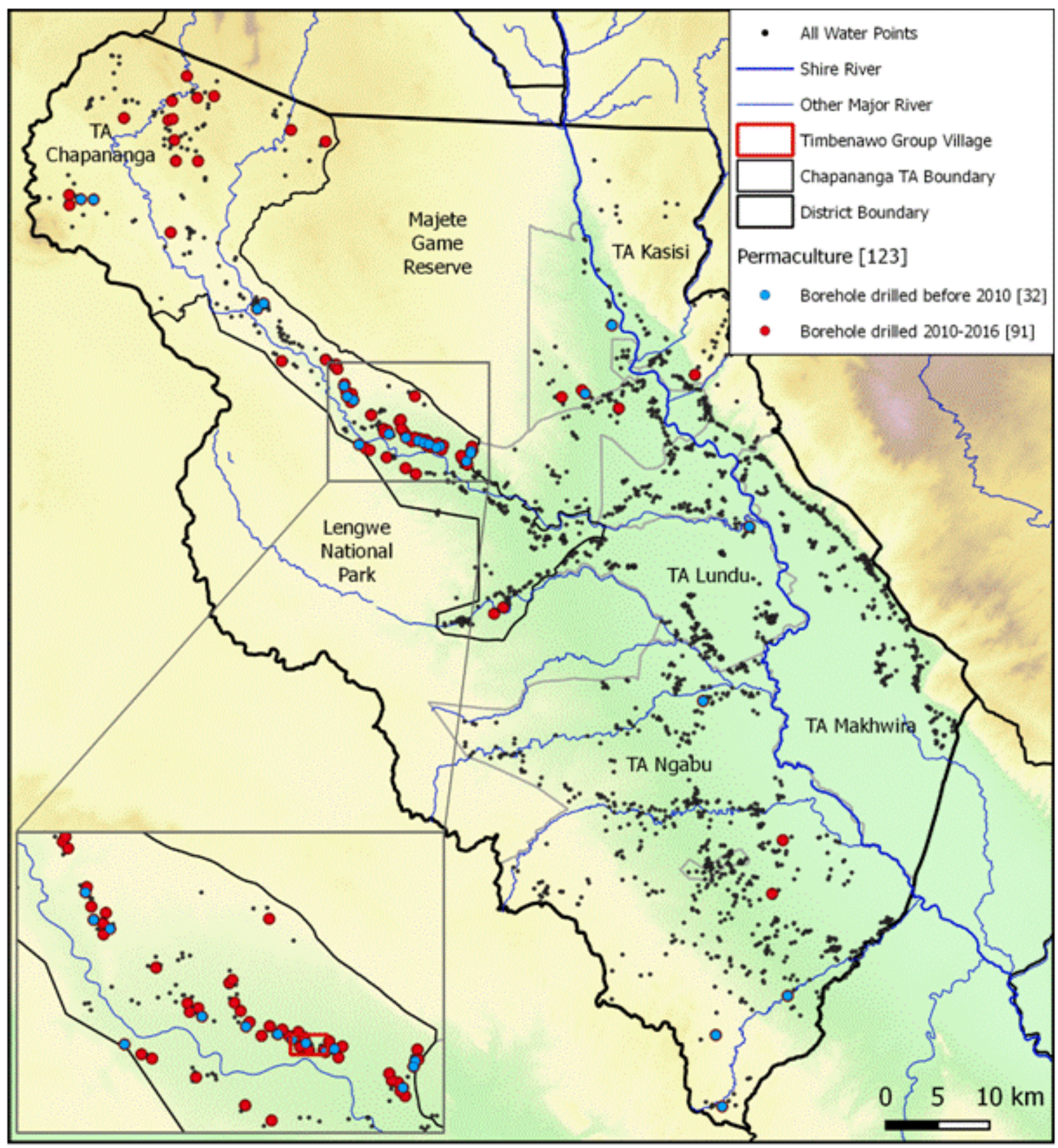


Figure 6.

- Strong sense of community spirit

-Willing to work together for village betterment

- Resident skills and le adership base

- Above factors suggest potential for success
- Drought and flood, climate change

- Borehole breakdown

- Poor performance of chiefs, Water Point

Committees, villagers

- Confused ownership, disenfranchised parties

- Overcoming te chnical garden problems

- Ministry capability to implement IWRM

- Cultural beliefs, Social issues

- Power to influence permaculture success

- Must understand benefits to improve prospects

- Potential to be included in inter-village

knowledge exchange

- Business opportunity to sell eco-fertiliser to gardens

- Permaculture garden as a marketing show garden

- Entrepreneurial spirit could drive garden success

- Potentially could instate on Water Point Committee

Challenges

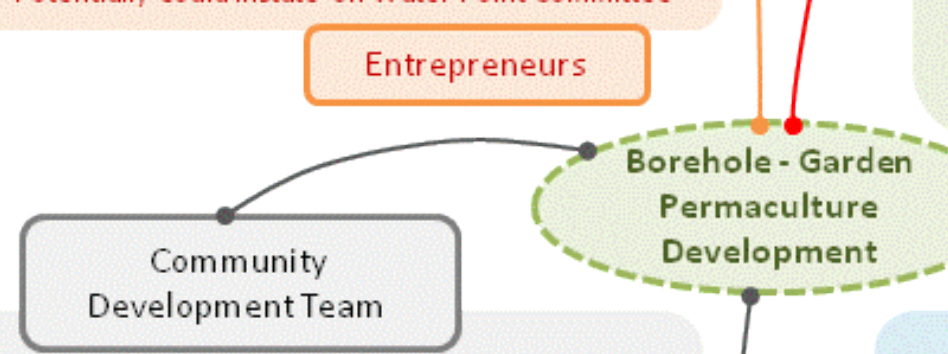

- Campaigning and training on permaculture

- Train Water Point Committee to include permaculture position with authority

- Teach communities on issues and benefits

- Liaise with NGOs / Ministries to draw on expertise

- Mitigates dise ase from stagnant water

- Re-use of water otherwise wasted

- Providesa community fund for borehole maintenance

- Perennial food source and some food/ nutrition security

- Community empowerment activity

- May address social-gender issues

- Increases sustainability of water resources

- Opportunity for economic development

\section{Government - District Executive Committee}

\section{Ministry of Agriculture}

- Capacity building of ADOs critically required to underpin permaculture - Training on eco-fertiliser may help move from subsidised fertiliser - Permaculture training would enhance current efforts and foster incre ase dinvolvement in gardens - Improved alignment with other arms of government
- Improve inter-ministry communication

- Adopt structures that facilitate IWRM

- Improve control over NGOS

- Enforce proper training

- Undertake capacity building

- Lobby government for funding. appropriate regulatory controls

Ministry of Health \& Sanitation

\section{Benefits}

- Crucial to permaculture success

- Improve alignment with government agenda

- Target stagnant pond borehole implementation

- Target synergies with new borehole drilling phases

- Significant training capability across stakeholders 
Figure 7.

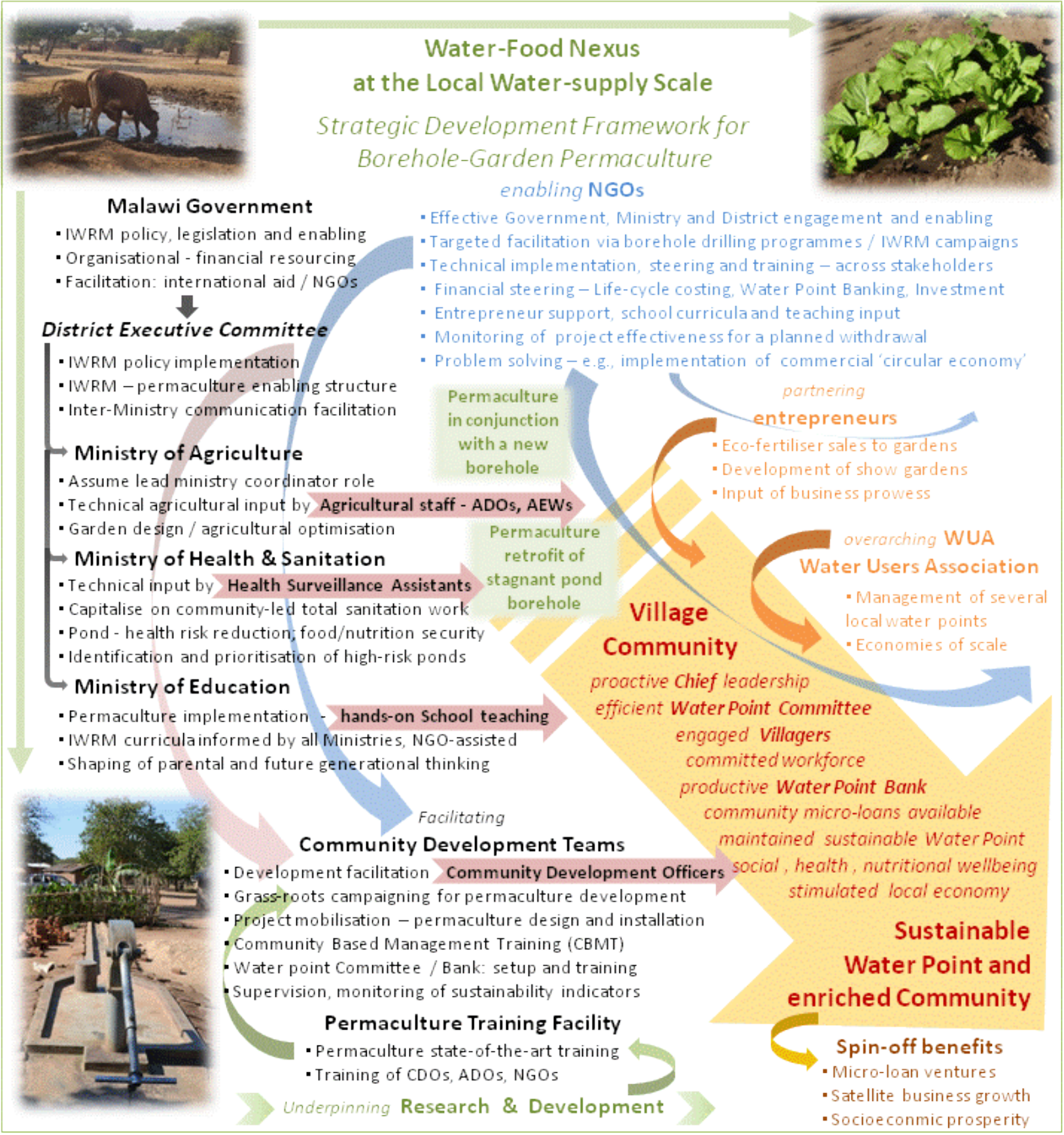




\title{
Journal of Environmental Management
}

\section{Supplementary Material}

for

\section{Local scale water-food nexus: use of borehole-garden permaculture to realise the full potential of rural water supplies in Malawi}

\author{
Michael O. Rivett ${ }^{1}$, Alistair W. Halcrow ${ }^{1}$, Janine Schmalfuss ${ }^{1}$, John A. Stark ${ }^{1,2}$, Jonathan P. \\ Truslove $^{1}$, Steve Kumwenda ${ }^{3}$, Kettie A. Harawa ${ }^{3}$, Muthi Nhlema ${ }^{4}$, Chrispine Songola ${ }^{5}$, Gift J. \\ Wanangwa ${ }^{6}$, Alexandra V.M. Miller ${ }^{1}$, Robert W. Kalin ${ }^{1}$ \\ ${ }^{1}$ Department of Civil and Environmental Engineering, University of Strathclyde, Glasgow, G1 \\ 1XJ, UK \\ ${ }^{2}$ Now at: EnviroCentre Ltd, Craighall Business Park, 8 Eagle Street, Glasgow, G4 9XA, UK \\ ${ }^{3}$ Water For People - Malawi, PO Box 1207, Blantyre, Malawi \\ ${ }^{4}$ BASEflow, Galaxy House, Blantyre, Malawi (formerly: Water for People - Malawi) \\ ${ }^{5}$ District Water Development Office, Chikwawa District Council, Private Bag 1, Chikwawa. \\ Malawi \\ ${ }^{6}$ Ministry of Agriculture, Irrigation and Water Development, Regional Irrigation and Water \\ Development Office - South, Private Bag 13, Blantyre, Malawi \\ Corresponding author: michael.rivett@strath.ac.uk
}

\section{Contents}

Figure SM-1. Mind-map summary of findings from Community Development Officer interviews.

Table SM-1. Semi-structured interview questions for Agricultural Extension Workers.

Table SM-2. Breakdown of annual operational costs for a permaculture borehole garden in Malawi.. Table SM-3 Breakdown of Capital investment costs for a permaculture borehole garden in Malawi. Table SM-4 Sensitivity of permaculture projected to occur across Chikwawa to assumptions on the percentage of boreholes checked for stagnant water occurrence. 


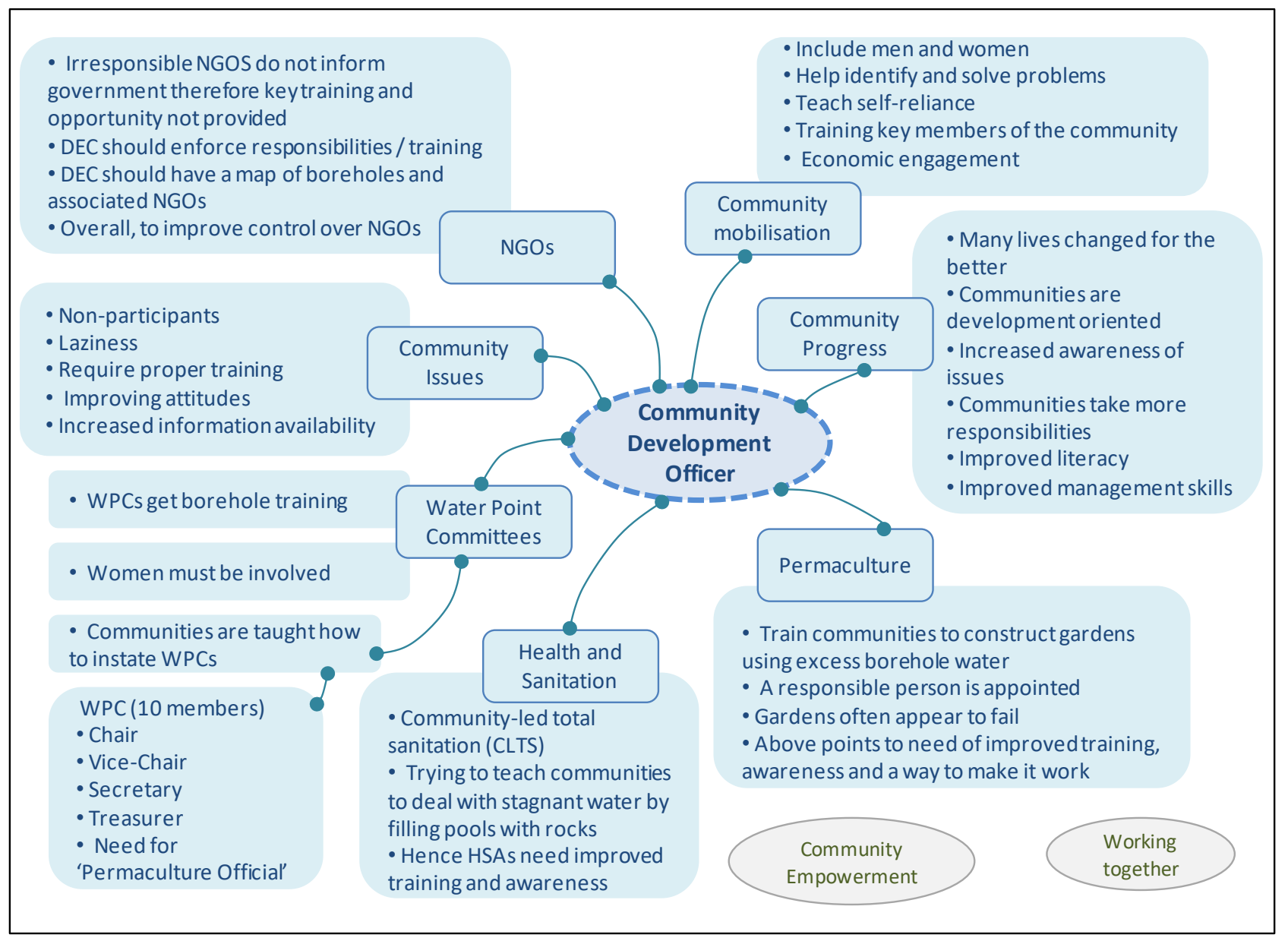

Fig. SM-1. Mind-map summary of findings from Community Development Officer interviews in 2013. 
Table SM-1. Semi-structured interview questions for Agricultural Extension Workers.

Questions for Agricultural Extension Workers

- What is your role as an Agricultural Extension Worker?

- In what ways do you provide support for small scale farmers?

- What are the main challenges for small scale farmers?

- Where do they normally get their fertiliser?

- How popular is eco-fertiliser? How do you feel about it?

- In what ways are you involved with the communities?

- Are you involved in any training? Who and what do you teach?

- What kind of training have you gone through yourself?

- Do you work together with other arms of the DCT? If so, who and how?

- Are you involved with an NGO?

- What do you know about permaculture?

- How do you see it practised in communities?

- Do you provide any advice on gardens using excess borehole water? If so, what?

- What do you think of these gardens?

- Why do you think they often fail?

- How do you think they can be made to work?

Table SM-2. Breakdown of annual operational costs for a permaculture borehole garden in Malawi.

\begin{tabular}{|l|c|}
\hline Item & $\begin{array}{c}\text { Cost } \\
\mathbf{\$}\end{array}$ \\
\hline Reparations (fences, channelling) & 100 \\
\hline Replacement plants, seeds and (eco-)fertiliser & 100 \\
\hline Harvest and transport to market & 100 \\
\hline $\begin{array}{l}\text { Supervision (by Community Development } \\
\text { Team in permaculture implementation) }\end{array}$ & 200 \\
\hline TOTAL & $\mathbf{5 0 0}$ \\
\hline
\end{tabular}


Table SM-3. Breakdown of Capital investment costs for a permaculture borehole garden in Malawi. Regarding fertiliser costs, for regular fertiliser is $\$ 42$ per bag, eco-fertiliser $\$ 0.60$ per bag or potentially free if a community harvests its own latrine.

\begin{tabular}{|l|c|}
\hline Item & $\begin{array}{c}\text { Cost } \\
\mathbf{\$}\end{array}$ \\
\hline Effective water channelling into the garden & 500 \\
\hline A sturdy fence to keep out free-range animal & 500 \\
\hline The purchase and transport of plants and seeds & 500 \\
\hline Operational training for villagers & 1,000 \\
\hline Installation of the garden & 500 \\
\hline (Eco-)fertiliser & $\begin{array}{c}\text { Variable, } \\
\text { potentially } \\
\text { negligible }\end{array}$ \\
\hline TOTAL COST & $\mathbf{3 , 0 0 0}$ \\
\hline
\end{tabular}

Table SM-4. Sensitivity of permaculture projected to occur across Chikwawa to assumptions on the percentage of boreholes checked for stagnant water occurrence (based on the four preferred crop $\$ 1130$ individual garden profit case).

\begin{tabular}{|c|c|c|c|c|c|}
\hline $\begin{array}{c}\text { Boreholes } \\
\text { checked } \\
\%\end{array}$ & $\begin{array}{c}\text { Number of } \\
\text { boreholes } \\
\text { checked }\end{array}$ & $\begin{array}{c}\text { Projected } \\
\text { boreholes for } \\
\text { permaculture }\end{array}$ & $\begin{array}{c}\text { Total } \\
\text { permaculture area } \\
\text { Ha }\end{array}$ & $\begin{array}{c}\text { Annual profit } \\
\text { per garden } \\
\$\end{array}$ & $\begin{array}{c}\text { Chikwawa-wide } \\
\text { annual profit } \\
\$\end{array}$ \\
\hline 30 & 620 & 1930 & 193 & 1130 & $2,181,000$ \\
\hline 40 & 826 & 1449 & 145 & 1130 & $1,637,000$ \\
\hline 50 (assumed) & 1032 & 1159 & 116 & 1130 & $1,310,000$ \\
\hline 60 & 1239 & 966 & 96.6 & 1130 & $1,092,000$ \\
\hline 70 & 1446 & 828 & 82.8 & 1130 & 936,000 \\
\hline
\end{tabular}

